INTERNATIONAL MONETARY FUND

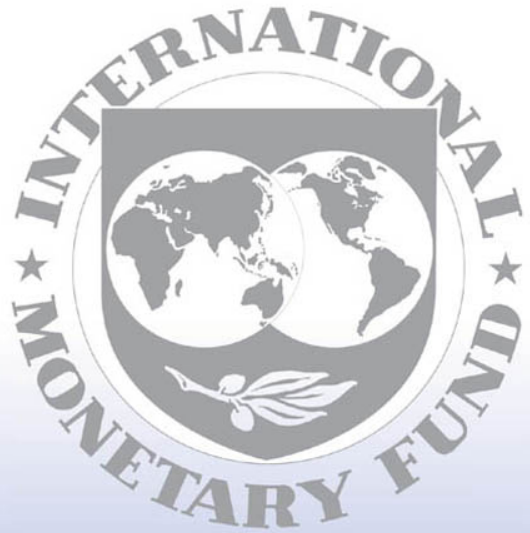

Staff

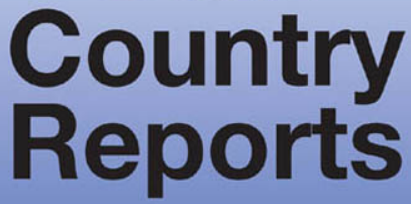




\title{
Liberia: First Review of Performance Under the Staff-Monitored Program-Staff Report; Press Release on the Executive Board Discussion; and Statement by the Executive Director for Liberia
}

In the context of the first review of performance under the Staff-Monitored Program, the following documents have been released and are included in this package:

- the staff report for the First Review of Performance Under the Staff-Monitored Program, prepared by a staff team of the IMF, following discussions that ended on July 28, 2006, with the officials of Liberia on economic developments and policies. Based on information available at the time of these discussions, the staff report was completed on September 14, 2006. The views expressed in the staff report are those of the staff team and do not necessarily reflect the views of the Executive Board of the IMF;

- $\quad$ a Press Release summarizing the views of the Executive Board as expressed during its October 2, 2006 discussion of the staff report; and

- $\quad$ a statement by the Executive Director for Liberia.

The document listed below has been or will be separately released.

Letter of Intent sent to the IMF by the authorities of Liberia*

*Also be included in Staff Report

The policy of publication of staff reports and other documents allows for the deletion of market-sensitive information.

To assist the IMF in evaluating the publication policy, reader comments are invited and may be sent by e-mail to publicationpolicy@imf.org.

\author{
Copies of this report are available to the public from \\ International Monetary Fund • Publication Services \\ $70019^{\text {th }}$ Street, N.W. • Washington, D.C. 20431 \\ Telephone: (202) 623-7430 • Telefax: (202) 623-7201 \\ E-mail: publications@imf.org • Internet: http://www.imf.org
}

Price: $\$ 18.00$ a copy

\section{International Monetary Fund Washington, D.C.}


This page intentionally left blank 
INTERNATIONAL MONETARY FUND

LIBERIA

First Review of Performance Under the Staff-Monitored Program

Prepared by the African Department

(In consultation with other departments)

Approved by David Andrews and Matthew Fisher

September 14, 2006

- Discussions for the first review of performance under the February-September 2006 staff-monitored program (SMP) took place in Monrovia during July 20-28, 2006.

- The staff team comprised Mr. Powell (head), Mr. Erasmus and Mr. Leichter (all AFR), Mr. Arnason (PDR), Mr. Nyberg (FIN), and Mr. Tharkur, (Resident Representative). Mr. Mamba, advisor to the Executive Director, and World Bank staff participated in some discussions.

- The staff met with the ministers of Finance, Planning and Economic Affairs, Lands, Mines and Energy, and Agriculture, as well as the Governor of the Central Bank of Liberia, other senior government officials, private sector representatives, and the donor community. The staff also briefed President Johnson-Sirleaf on the mission's preliminary findings.

- In an updated Letter of Intent (Appendix I), the authorities request, based on their performance under the SMP to date, that the Fund begin de-escalating the remedial measures which are being applied against Liberia.

- The security situation in Liberia remains relatively stable. Forces of the United Nations Mission (UNMIL) in Liberia continue to respond quickly to isolated incidents of unrest. 


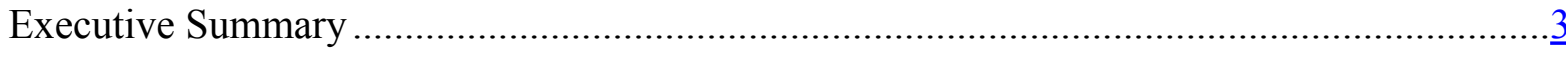

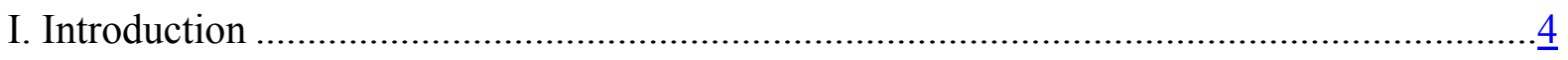

II. Recent Developments and Performance Under the Program.........................................

III. Policy Discussion and the Outlook for the Remainder of 2006 ....................................

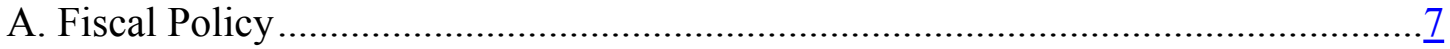

B. Monetary Policy and Financial Sector Issues ................................................ $\underline{9}$

C. Economic Governance .......................................................................... 11

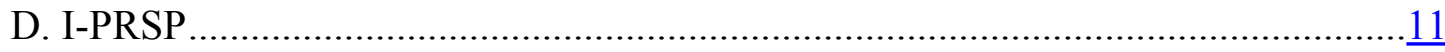

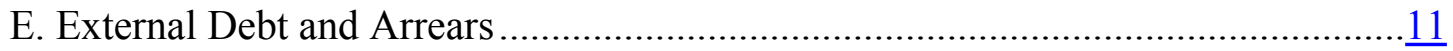

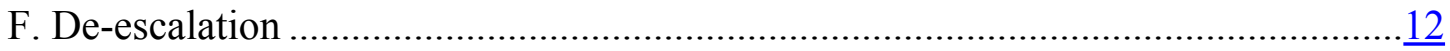

IV. Program Risks and Monitoring ......................................................................

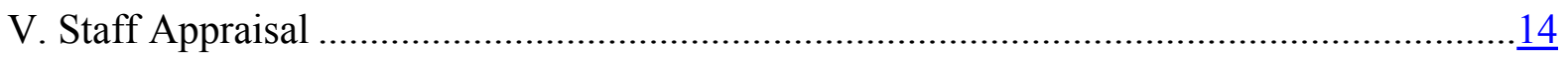

Tables

Table 1. Selected Economic and Financial Indicators, 2003-07 .......................................18

Table 2. Balance of Payments, 2003-07 ........................................................................

Table 3. Summary of Central Government Operations, 2002/03-2006/07 ..........................20

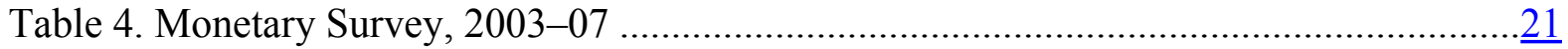

Table 5. Medium-Term Scenarios, 2006-11 …............................................................22

Figures

Figure 1. Selected Economic Indicators, 2000-06 …................................................ 15

Figure 2. Exchange Rates Developments, January 2000-May 2006 .................................17

Boxes

Box 1. Domestic Debt and Arrears ......................................................................... 10

Box 2. The Fund's Support for Capacity Building in Liberia .........................................13

Appendixes

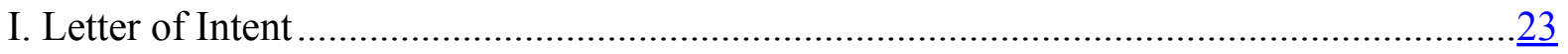

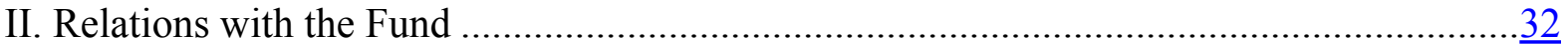

III. Relations with the World Bank Group ................................................................... $\underline{36}$

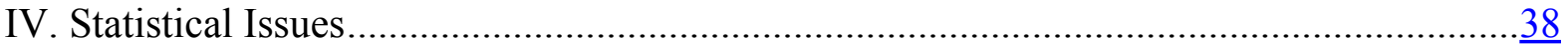




\section{EXECUTIVE SUMMARY}

- Economic developments are broadly in line with the original program projections for the year. Real GDP growth is expected to continue to recover to about 8 percent, from 5.3 percent in 2005 , while inflation is expected to remain in single digits. A significant increase in world rubber prices this year is expected to boost rubber export receipts, more than offsetting the projected increase in the oil import bill.

- The authorities have made considerable progress in implementing the SMP, and the program is broadly on track. All of the SMP's quantitative benchmarks for March and June were met, as were most of the structural benchmarks, albeit some with delays.

- Financial management has been significantly strengthened under the new government. Substantial efforts to improve revenue administration raised revenue by 18 percent in February-June 2006, compared with the corresponding period in 2005. Adherence to the strengthened commitment control system ensured that the Bureau of Budget (BoB) did not make allotments to line ministries in excess of available revenues.

- The financial position of the Central Bank of Liberia (CBL) also improved. A strong effort to control expenditure, together with a delay in payment for the printing of new currency, resulted in a deficit of US $\$ 0.4$ million at end-June, compared with a budgeted deficit of US\$2.5 million.

- The budget for fiscal year 2006/07 (July-June) was approved by the legislature on August 22. The approved budget is ambitious, with revenue projected to rise 43 percent over the estimated outturn for $2005 / 06$. Preparation of prioritized monthly cash plans by line ministries will therefore be important to ensure that expenditure cuts can be made without affecting core functions of line ministries should revenue fall short of projections.

- Looking ahead, while the authorities remain strongly committed, there are some risks to the program. Difficult relations with the legislature, which delayed passage of the 2006/07 budget, could also impede important policy initiatives. Serious capacity constraints are also likely to affect the ability of the authorities to achieve all of the objectives under the SMP in a timely manner. Strong support from donors remains critical. 


\section{INTRODUCTION}

1. The government of President Ellen Johnson-Sirleaf took office on January 16, 2006. The authorities quickly requested Fund staff assistance in developing a program to support economic reconstruction, and to begin building a track record needed for the eventual resolution of Liberia's arrears and debt overhang. An SMP for February-September 2006 was agreed with the staff in February 2006 and approved by Fund Management in early April. The key objectives of the SMP are to rebuild public institutions, restore credible financial management, and accelerate structural reforms. To this end, the program incorporates ambitious macroeconomic and structural targets. Full details of the authorities' program and its objectives were presented in IMF Country Report No. 06/166. This paper provides an update on recent economic developments and progress under the SMP in the period through end-June 2006. It is accompanied by a separate paper reviewing Liberia's overdue obligations to the Fund.

\section{Recent Developments And Performance Under the Program}

\section{Economic developments in the first half of $\mathbf{2 0 0 6}$ appear broadly in line with the} staff's earlier projections. Inflation has remained relatively stable, with year-on-year inflation at 6.6 percent in June, compared with 7 percent in December 2005. ${ }^{1}$ The Liberian dollar has traded in a narrow range between 56 and 59 Liberian dollars per U.S. dollar during January-June 2006; the real effective exchange rate depreciated by 8.6 percent (end-May) from end-2005. Broad money (which excludes U.S.

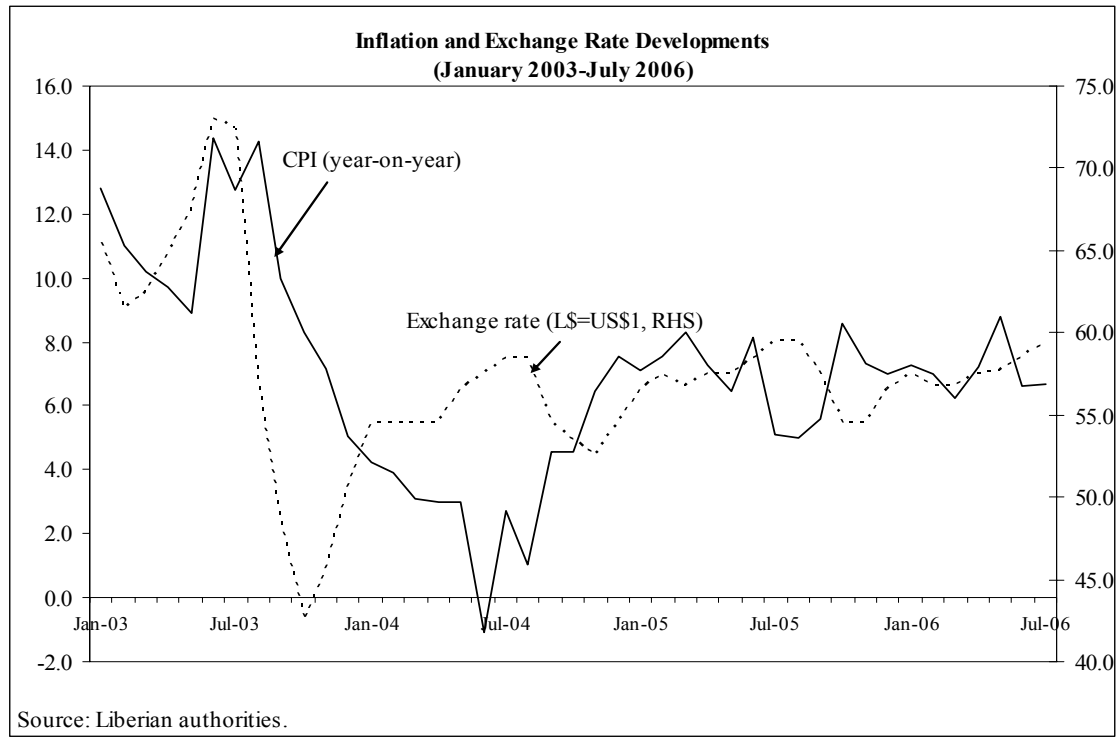
dollars circulating outside banks) expanded at rates in the range of 25-40 percent (year-onyear) during January-June 2006. The economy is expected to continue its recovery during 2006, with real GDP growth projected to rise to 7.7 percent from an estimated 5.3 percent in

\footnotetext{
${ }^{1}$ Liberia currently imports most consumer goods. Although both the Liberian and U.S. dollars are legal tender, prices are generally denominated in Liberian dollars, and price developments therefore benefited from exchange rate stability in the first six months of 2006.
} 
2005, and inflation remaining in single digits. The trade deficit is projected to remain largely unchanged, with an expected increase in rubber exports (on account of a substantial increase in world rubber prices) offsetting the increase in the oil import bill.

3. Fiscal management has greatly improved under the new government. Revenues rose substantially during February-June 2006 as the government made a strong effort to improve tax and customs administration. ${ }^{2}$ Actual revenues were 19 percent higher than projected in the recast budget (February-June), which was approved by the legislature in early April. On the expenditure side, the late approval of the recast budget, strengthening of the interim commitment control system, and introduction of the Public Procurement and Concessions Act, significantly delayed spending approvals during February-May, and resulted in the accumulation of sizable balances in the government's accounts at the CBL. However, the pace of expenditure approvals by the Cash Management Committee (CMCo) picked up notably in late-May and June, and most of the balance in the government account at the CBL at end-June represented checks issued, but not yet cashed in fiscal year 2005/06 (Text Table).

Liberia: Implementation of 2005/06 Recast Budget (February-June 2006)

\begin{tabular}{|c|c|c|c|}
\hline & \multirow{2}{*}{$\begin{array}{l}\text { Recast } \\
\text { budget }\end{array}$} & \multicolumn{2}{|c|}{ Estimated outturn } \\
\hline & & $\begin{array}{l}\text { Cash } \\
\text { basis }\end{array}$ & $\begin{array}{r}\text { Commitment } \\
\text { basis } \\
\end{array}$ \\
\hline & \multicolumn{3}{|c|}{ (Millions of U.S. dollars) } \\
\hline Total Revenue and grants & 38.9 & 46.1 & 46.1 \\
\hline of which: grants & $\ldots$ & 1.0 & 1.0 \\
\hline Total expenditure and net lending & 44.1 & 31.7 & 49.1 \\
\hline Overall surplus/deficit & -5.2 & 14.4 & -3.0 \\
\hline GOL account at CBL (beginning of period) (cash basis) & 5.3 & 5.3 & 5.3 \\
\hline GOL account at CBL (end of period) $1 /$ & 0.0 & 19.5 & 2.3 \\
\hline
\end{tabular}

1/ Cash basis balance is actual balance on June 30 converted using the market exchange rate.

Sources: Liberian authorities; and Fund staff estimates and projections.

\footnotetext{
${ }^{2}$ These measures include the enforcement of preshipment inspections for imports and exports, strengthened tax collection, and the elimination of noncash payment of taxes.
} 
4. The government has also made progress in improving governance. As agreed under the Governance and Economic Management Assistance Program (GEMAP), ${ }^{3}$ international experts were deployed to the main revenue-generating agencies, the $\mathrm{CBL}$, the BoB, and the Ministry of Lands, Mines and Energy. The authorities also finalized a framework for reviewing concessions and contracts originated under the National Transitional Government of Liberia (NTGL), and prepared a draft anticorruption policy paper to guide preparation of the anticorruption strategy. In the area of civil service reform, the authorities have begun reducing the number of ghost workers and political appointees in the civil service, drafted a civil service code of conduct, and required all serving ministers to publicly declare their assets.

5. UN sanctions on timber exports were provisionally lifted on June 20, 2006, though sanctions on diamond exports were extended for a further period of six months. The permanent removal of the timber sanctions is subject to the adoption of appropriate forestry legislation. The removal of sanctions is not expected to have a significant impact on economic activity in 2006, although timber-related exports and tax receipts are projected to pick up during 2007.

6. The authorities have made considerable progress in implementing the SMP in the period through end-June 2006, and the program was broadly on track. Paragraphs 4-10 of Appendix I (the Letter of Intent) provide further details of this performance. In particular, all the quantitative benchmarks under the program through end-June were achieved (Table 1A, Appendix I), as were most of the structural benchmarks, albeit some with temporary delays (Table 2, Appendix I).

\section{Policy Discussion ANd the OUtlook For The Remainder OF 2006}

7. A continued strong effort will be required to implement the outstanding structural benchmarks under the SMP by the end of September. ${ }^{4}$ Discussions during the mission focused on actions required to ensure that remaining structural benchmarks can be met. Given serious capacity constraints, which the authorities described as being greater than

\footnotetext{
${ }^{3}$ The GEMAP agreed to in September 2005 by the National Transitional Government of Liberia and key international partners aims to strengthen economic governance, and is intended to remain in effect until Liberia reaches the HIPC completion point. See IMF Country Report No. 06/166, attachment III.

${ }^{4}$ The macroeconomic assumptions underlying the program through September and the medium term remain largely unchanged from the original program projections (Table 5). The baseline and lower-case scenarios were updated to reflect the lifting of UN sanctions on timber exports, and potential lifting of diamond sanctions by end-2006. However, this does not fundamentally impact the baseline scenario projections as the staff had already anticipated a recovery in forestry production in 2007.
} 
expected when they took office, timely donor support remains critical for achieving the SMP's objectives.

\section{A. Fiscal Policy}

\section{The authorities submitted a cash-based balanced budget for 2006/07 to the} legislature on June 29, which was approved by the legislature on August 22. ${ }^{5}$ The budget targets an increase in revenues of 43 percent over the 2005/06 fiscal year, based on expectations of continued progress in strengthening revenue administration, further reduction in tax and tariff exemptions, collection of overdue taxes, and a continued economic recovery. ${ }^{6}$ On the expenditure Revenue Projections: 2005/06 vs. 2006/07 side, the budget reallocates government resources to pro-

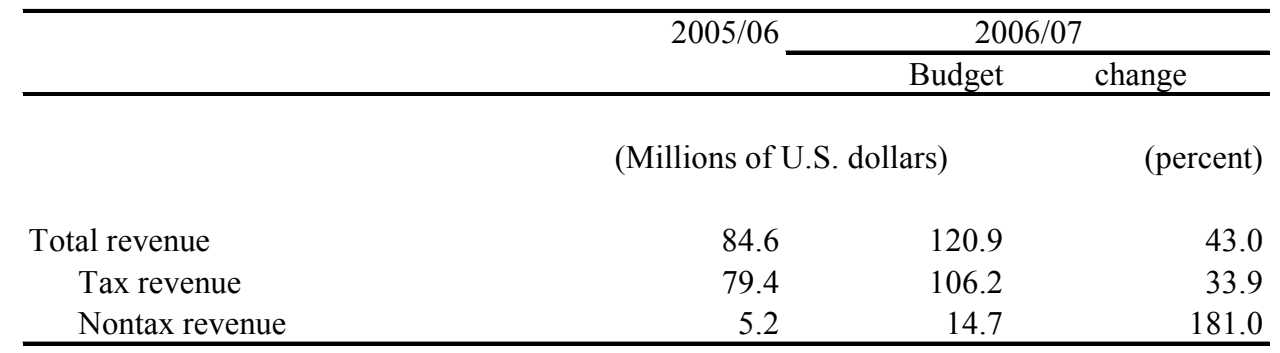
poor sectors, and the budget for the social services subsector, which Source: Liberian authorities. includes education and health, has been increased by 56 percent relative to the annualized recast budget, to a quarter of all government expenditure. The budget also provides for an increase in the wage bill by 51 percent, inter alia raising the salaries of the lowest paid civil servants from US\$15 per month to US\$30 per month. The World Bank staff indicated that they consider the composition of expenditures in the budget to be broadly appropriate.

\footnotetext{
${ }^{5}$ The budget approved by the legislature, and signed into law by the President on August 28, differed only marginally from that submitted by the President. It provides for transfers from two state owned enterprises amounting to US $\$ 750,000$, raising projected revenues to US\$120.9 million. It also shifted US\$2 million, originally earmarked for supplementary wage increases in the contingent expenditure category, to the main budget, but compensated for this by shifting an equal amount originally targeted for domestic arrears clearance in the main budget to contingent expenditure. The budget provides for contingent expenditures in the amount of US\$9 million.

${ }^{6}$ The reduction of duty and tax exemptions on rice and petroleum is expected to increase revenue from these sources from US $\$ 0.6$ million in $2005 / 06$ to US $\$ 10.3$ million in $2006 / 07$, and from US\$4.1 million to US\$13.8 million respectively, while collection of overdue taxes is expected to contribute US $\$ 4.8$ million to revenue in 2006/07; higher revenue from these sources represent about 80 percent of the projected increase in public revenue. Other measures implemented to contribute to 2006/07 revenue include: (i) application of the goods and services tax (GST) on imports to the duty paid value; (ii) application of the GST on domestic supplies on the sales price, inclusive of excise taxes; (iii) application of a uniform excise tax of 15 percent on imported and domestic alcoholic beverages, and increasing excise tax on cigarettes to 15 percent; and (iv) updating the unit values on which land and building taxes are based.
} 
9. Achieving the revenue target will require substantial effort to further strengthen tax and customs administration. Staff emphasized the importance of further reducing tax exemptions, including through the timely completion of the contracts and concessions review, and further strengthening the Large Taxpayers Unit (LTU). The authorities noted that implementation of the strategy for the collection of overdue tax payments (see Appendix I, paragraph 5) is expected to boost revenues in the second half of the fiscal year, while a further strengthening of the LTU would be considered drawing on advice from FAD on revenue administration. ${ }^{7}$

10. The staff emphasized the importance of strictly adhering to prioritized monthly cash plans to ensure that expenditures do not exceed available revenues. Since revenue projections are subject to significant uncertainty, contingent expenditures would need to be identified in each line ministry's cash plan so that expenditures can be appropriately adjusted, should the need arise. The authorities confirmed that prioritized monthly cash plans will guide budget implementation in 2006/07 to ensure that appropriate expenditure adjustments can be made.

11. The commitment control system has been considerably strengthened. The staff welcomed the rigorous implementation of this system, but noted that it had led to uneven monthly expenditures during February-June, and that a large quantity of purchase orders had been approved toward the end of the fiscal year. The authorities stressed that all regulations were observed, but agreed that implementation of the new procurement guidelines requires continued assistance to line ministries to ensure that voucher requests are supported by appropriate documentation and are approved in a timely manner. In the absence of an approved 2006/07 budget, the CMCo could not approve any expenditure during July and most of August. ${ }^{8}$ The authorities informed the staff that line ministries were able to continue functioning during the initial part of the fiscal year on the basis of the surge in expenditure approvals in late-May and June.

\section{The authorities indicated that no new arrears had been accumulated from mid-} January through end-June. They noted that public notices in April and July had made it clear that commitments not accompanied by a CMCo voucher (with Bureau of General Accounting (BGA) seal) were not a legal claim on the government. The staff nonetheless

\footnotetext{
${ }^{7}$ A recent FAD TA mission recommended a number of measures to strengthen the LTU, including to:

(i) transfer responsibility for nontax revenues to the Bureau of Internal Revenue; (ii) reduce the threshold to a level that results in at least 70 percent of total collections being administered by the LTU; (iii) ensure that the LTU assumes responsibility for all tax administration functions for large taxpayers; (iv) increase the LTU staff to 35-40; and (v) establish a substantive audit capability in the LTU.

${ }^{8}$ Liberian budget law provides for a continuing resolution allowing expenditure up to one-third of the previous year's budget. The authorities, however, elected not to request legislative approval of such a resolution.
} 
urged the government to continue providing guidance to line ministries to ensure that no new commitments are made without first securing an approved purchase order. However, available information suggests that wage arrears relating to wages for July may have been incurred; in accordance with regulations, civil service wages are due within the first week following the end of a calendar month; this would constitute a breach of a continuous quantitative benchmark.

13. Progress on the verification of the government's domestic debt arrears has been slower than envisaged under the program (Box 1). The staff emphasized the importance of completing the verification of domestic claims, and of finalizing a debt resolution strategy, in part, since finalization of such a strategy would be an important element of ongoing efforts to strengthen the financial sector. The authorities agreed, and confirmed their intention to complete the verification of these claims and finalize the strategy by end-September.

\section{B. Monetary Policy and Financial Sector Issues}

14. Monetary policy aims to contain inflation by maintaining a stable exchange rate. Consistent with the SMP, regular foreign exchange auctions have been held since endMarch. The staff, however, noted that the currency had depreciated toward the bottom of the range considered by the authorities to be broadly consistent with exchange rate stability. The CBL agreed with the staff's suggestion that the Liberian dollar component of money supply should be expanded cautiously to maintain a broadly stable exchange rate.

\section{The framework for monetary policy implementation has been strengthened} since February. The authorities noted that the focus of the Money Management and Policy Review Committee had been clarified, and that it regularly considered a broad range of economic indicators in assessing domestic liquidity developments. The staff encouraged the authorities to begin using the liquidity monitoring framework which had been revised with assistance from MFD.

16. The staff welcomed the improvement in the financial position of the CBL, and noted the importance of adhering to the budget for the remainder of the year in order to cement the gains achieved thus far. Noting that the financial health of the CBL remains vulnerable on account of large unremunerated claims on the government, the staff stressed that the CBL should further improve its financial position during 2007, and should target a balanced cash-based budget. CBL staff concurred with the mission that the operations of the CBL should not continue to be a drain on Liberia's scarce foreign reserves, and noted that improving the CBL's income position by resolving the government's arrears to the bank was a priority. 


\section{Box 1. Liberia: Domestic Debt and Arrears}

Domestic debt and arrears on March 31, 2006 are estimated at US\$754 million, or 142 percent of 2005 GDP, of which US $\$ 483$ million has been internally verified.

- $\quad C B L$ debt - The CBL is the largest creditor with US\$260.9 million of verified claims. Discussions on a comprehensive debt restructuring plan are under way.

Domestic Debt and Arrears (March 31, 2006) (In millions U.S. dollars)

- Commercial bank debt - The total debt owed to commercial banks is US\$20.5 million.

$\begin{array}{lr}\text { Total } & \mathbf{7 5 4} \\ \text { Total for pre-NTGL period } & \mathbf{7 1 1} \\ \text { verified } & 440 \\ \text { debt to CBL } & 261 \\ \text { debt to banks } & 19 \\ \text { salary arrears } & 19 \\ \text { SOEs, vendors and bonds } & 141 \\ \text { unverified } & 271 \\ \text { debt to banks } & 1 \\ \text { SOEs, vendors and bonds } & 270 \\ \text { Total for NTGL period } & \mathbf{4 3} \\ \text { verified } & 15 \\ \text { unverified } & 28\end{array}$

Building on the work of the National Debt Management Task Force established in July 2004, the new government created an interministerial vetting committee comprising senior officials from the MoF, CBL and other agencies. The committee began meeting in June and is tasked with vetting domestic debt and arrears, and recommending to the government strategies for resolving these claims. In addition, the committee is expected to recommend a roadmap for developing a national debt management strategy.

Regarding the vetting of claims, the government has decided to hire an external auditor for claims above US\$10,000 for services, US\$25,000 for goods, and US\$50,000 for public works. The tender closed in late July. These claims constitute 95 percent of pre-NTGL domestic debt and arrears under consideration; the interministerial vetting committee will consider the rest. A domestic debt resolution strategy is expected by end-September.
Expenditure on Arrears since February 2006

(In millions U.S. dollars)

\begin{tabular}{lr}
\hline & \multicolumn{2}{c}{$\begin{array}{c}\text { Recast Budget (Feb.-Jun.) } \\
\text { commitment basis }\end{array}$} \\
\cline { 2 - 3 } Total & $\mathbf{8 . 6}$ \\
of which salary arrears (NTGL period) & 3.8 \\
of which LIMINCO arrears (pre-NTGL \& NTGL) & 1.5 \\
of which salary arrears (pre-NTGL period) & 2.0 \\
& $\mathbf{2 0 0 6 / 0 7}$ Budget \\
\cline { 2 - 3 } Domestic debt (non salary arrears) & Proj. \\
Expenditure in contingent expenditures category & $\mathbf{4 . 0}$ \\
of which salary arrears (pre-NTGL) & $\mathbf{7 . 8}$
\end{tabular}

Previous TA on domestic debt focused on a subset of salary arrears, vendor claims and savings bonds. It recommended that salary arrears be paid in full and that vendor claims and bonds be settled at a discount rate that increases with the size of the claim. Small claims would be settled in full.

17. The staff and the authorities discussed the importance of finalizing restructuring strategies for the banking sector. The staff considered it important that the CBL and the two commercial banks with large unremunerated claims on the government, cooperate in preparing an assessment of the impact of possible alternative scenarios for resolving this 
debt, as this could be a useful input in finalizing the domestic debt resolution strategy which is targeted for end-September.

\section{Economic Governance}

18. In a sharp break with the past, the authorities have made considerable progress in strengthening economic governance. The staff welcomed progress to date, but stressed the importance of completing the review of contracts and concessions as soon as possible. The authorities concurred, but noted that delays in commencing the review process was due in part to delays in finalizing donor financing for the international experts who, under the GEMAP-approved framework, must participate in the review.

19. The staff welcomed the draft anticorruption policy paper, but urged the authorities to complete a comprehensive national anticorruption strategy, including an implementation matrix, with assistance from their international partners. The authorities acknowledged the importance of finalizing this strategy, but noted that the government was still considering the appropriate institutional framework, particularly whether an independent anticorruption institution should be established, or whether the strategy should be pursued within the existing judicial system.

\section{I-PRSP}

20. The authorities have made substantial progress in preparing an Interim Poverty Reduction Strategy Paper (I-PRSP). A draft I-PRSP is being finalized in consultation with the various stakeholders and development partners. The authorities aim to submit the finalized I-PRSP paper to the staffs of the Fund and World Bank by end-September. The Fund staff has been providing assistance in its areas of expertise, including in the development of updated baseline and alternative medium-term macroeconomic scenarios.

\section{E. External Debt and Arrears}

21. The authorities remain keenly interested in pursuing arrears clearance and debt relief. The staff indicated that, while it was too early for a precise timetable, strong performance under the SMP would be a precondition for moving forward. The staff also indicated that any consideration of a rights accumulation program (RAP) following the SMP will require adequate financial assurances to cover the Fund's subsequent debt relief to Liberia. The staff urged the authorities to continue their work with bilateral and commercial creditors to reconcile loan-by-loan debt data, as this would facilitate the preparation of a preliminary HIPC document. Some progress has already been made in this area; Paris Club creditors have 
provided updated creditor statements and copies of most of the original commercial loan agreements have been obtained. ${ }^{9}$

\section{F. De-escalation}

22. Based on their performance under the SMP thus far, the authorities request that the Fund begin de-escalating the remedial measures being applied against Liberia (Appendix I). The staff's assessment of this request and recommended decision are provided in the companion paper that reviews Liberia's overdue obligations to the Fund.

\section{Program Risks ANd Monitoring}

23. The authorities have made encouraging progress under the SMP, and remain strongly committed to implementing policies under the program. Nonetheless, there is some uncertainty going forward. The main risks to the program arise from capacity constraints in ministries and the tensions between the government and the legislature.

- Delays in the execution of spending in February-May and in the implementation of key structural measures under the SMP were in part caused by capacity limitations. This could continue to be a problem in the period ahead. Timely TA from the international community is a pre-condition for success. The Fund has already provided extensive TA to the new government in the areas of fiscal and monetary policy, and statistics (see Box 2).

- Tensions between the government and the legislature have delayed key legislation, including the budget for the 2006/07 fiscal year, which complicated expenditure management at the beginning of the fiscal year. The ability of the government to ensure passage of important legislation, including integrating the BoB and the Bureau of Maritime Affairs into the Ministry of Finance, will depend on the president's ability to develop a working relationship with the legislature.

24. Performance under the SMP will be monitored on the basis of quantitative and structural benchmarks for end-September (Tables 1B and 2 attached to the Letter of Intent). The end-September floor on revenue collections has been raised to make it consistent with the 2006/07 budget. The floor on the cash-based fiscal balance has also been revised to allow for the clearance of checks issued before the end of the 2005/06 fiscal year, and to spend the uncommitted balance at the CBL at end-June 2006. Moreover, for the CBL, the quantitative benchmarks have been revised to reflect the actual outturn to end-June 2006. Going forward, the staff has recast the quantitative benchmarks as cumulative targets rather

\footnotetext{
${ }^{9}$ Non-Paris Club bilateral debt (China, Kuwait, Saudi Arabia, and Taiwan Province of China) at end-2005 accounted for about 3 percent of total debt outstanding.
} 
25. than as quarterly flow targets to allow carry-over from one quarter to the next of unspent balances, as well as not to automatically raise (or lower) the CBL's reserve accumulation target in case of over-(or under-) performance in one quarter. Preliminary quarterly benchmarks were agreed for the budget for the remainder of the 2006/07 fiscal year (Table 1B) as a precursor to a possible RAP.

\section{Box 2. The Fund's Support for Capacity Building in Liberia}

The Fund has been providing extensive TA to the authorities since the new government took office in mid-January 2006. The authorities have been very receptive of the Fund's support for their efforts to enhance capacity, and have already implemented a number of TA recommendations.

In terms of its assistance to the GEMAP, the Fund supported the deployment of an international expert as Chief Administrator (CA) to the CBL since February 2006. The CA has made a significant contribution to the improvement in the financial management at the CBL and its strong performance under the SMP to date. The CA's term has been extended for one year to August 2007.

Fund TA has been instrumental in formulating a monetary policy framework for Liberia in the current highly dollarized economy, and addressing Liberia's weak financial sector. Based on Fund TA recommendations, the authorities publicized the monetary policy framework, reinstated regular foreign exchange auctions, and strengthened the terms of reference of the Money Management Committee. Fund staff also assisted the authorities in establishing a Bank Restructuring and Resolution Policy, and in improving supervision of troubled banks.

Continuous assistance from the Fund's regional advisor on public financial management has been central in strengthening the interim commitment control system. The authorities implemented a key recommendation requiring purchase orders to be validated by the BGA to prevent unauthorized spending by line ministries. During the first eight months of 2006 the Fund also fielded missions on public financial management (focusing on budget planning, execution and monitoring), tax policy, and revenue administration. The budget for 2006/07 implemented a number of recommendations on tax policy, including imposing a uniform excise on alcoholic beverages, increasing the excise on cigarettes, and reducing the import tariffs on books and notebooks and zinc metal sheets.

Fund TA has also helped the authorities to rebuild Liberia's statistical database, which was destroyed during the civil war, and to improve data quality. In the first half of the year, the Fund fielded missions on government finance statistics and the consumer price index.

Additional TA planned for the remainder of the year includes two MFD missions to continue assistance in the financial sector, two FAD missions on revenue administration, the deployment of a regional public financial management expert to Monrovia, and two STA missions on monetary and balance of payments statistics.

Under the GEMAP, the authorities have also been receiving extensive assistance from key international donors, including the World Bank, UNMIL, EU, DFID, ECOWAS, and the United States. Assistance has focused on strengthening economic governance, and included deployment of international experts to key revenue-generating agencies, finalizing a framework for reviewing contracts and concessions originated under the NTGL, drafting an anticorruption policy paper, strengthening public procurement procedures, developing a domestic debt resolution strategy, and reform of the forestry sector (which enabled the provisional lifting of UN sanctions on timber exports). External assistance has also been critical in rebuilding Liberian institutions to ensure continued peace and stability following the eventual withdrawal of UNMIL forces. 


\section{Staff Appraisal}

26. Despite severe capacity constraints, the government has made considerable progress in recent months in implementing key policies under the SMP, and the program is broadly on track. The staff welcomes this progress, as well as the government's continued commitment to achieving the goals of the SMP.

\section{Most of the SMP's quantitative and structural benchmarks for end-March and}

end-June were met. Public expenditure management has improved through implementation of the interim commitment control system, and strengthened cooperation between line ministries, the Ministry of Finance, and the BoB. The government has commenced a program for reviewing concessions and contracts originated under the NTGL. Moreover, under the GEMAP, international financial experts have been deployed to the main revenue-generating agencies. Encouraging measures have also been taken to strengthen the management and operations of the CBL and to boost tax collection. Among measures where temporary delays have been encountered, it is important to quickly establish an anticorruption strategy in cooperation with international partners, and to finalize the verification of the stock of domestic debt without further delay so that a domestic debt resolution strategy can be developed.

28. The budget for $\mathbf{2 0 0 6 / 0 7}$ is based on an ambitious revenue target. Given the significant uncertainty about the pace at which revenues will increase over the course of the year, it will be particularly important for the government to adhere to prioritized monthly cash plans so that adjustments to actual expenditures can be made during the year, should the need arise. Similarly, approval of legislation to merge the BoB and the Bureau of Maritime Affairs into the Ministry of Finance will be critical to help further strengthen public financial management, and make budget implementation more effective.

29. Achieving all the end-September benchmarks on a timely basis will be challenging. Finalizing the review of concessions and contracts is likely to take longer than originally planned although many of the major contracts should have been considered by end-September. This review is particularly important for reducing the number of tax exemptions, and hence raising government revenues. Similarly, finalization of a domestic debt resolution strategy, consistent with a plan for restructuring the CBL will require a sustained effort. The Fund will continue to provide timely technical assistance in its areas of expertise including tax administration, public financial management, the financial sector, and statistics.

30. Liberia's external debt is clearly unsustainable. However, the staff believes that achieving the objectives of the SMP will provide a basis for generating the support from the international community required to resolve Liberia's large external debt overhang. 
Figure 1. Liberia: Selected Economic Indicators, 2000-06
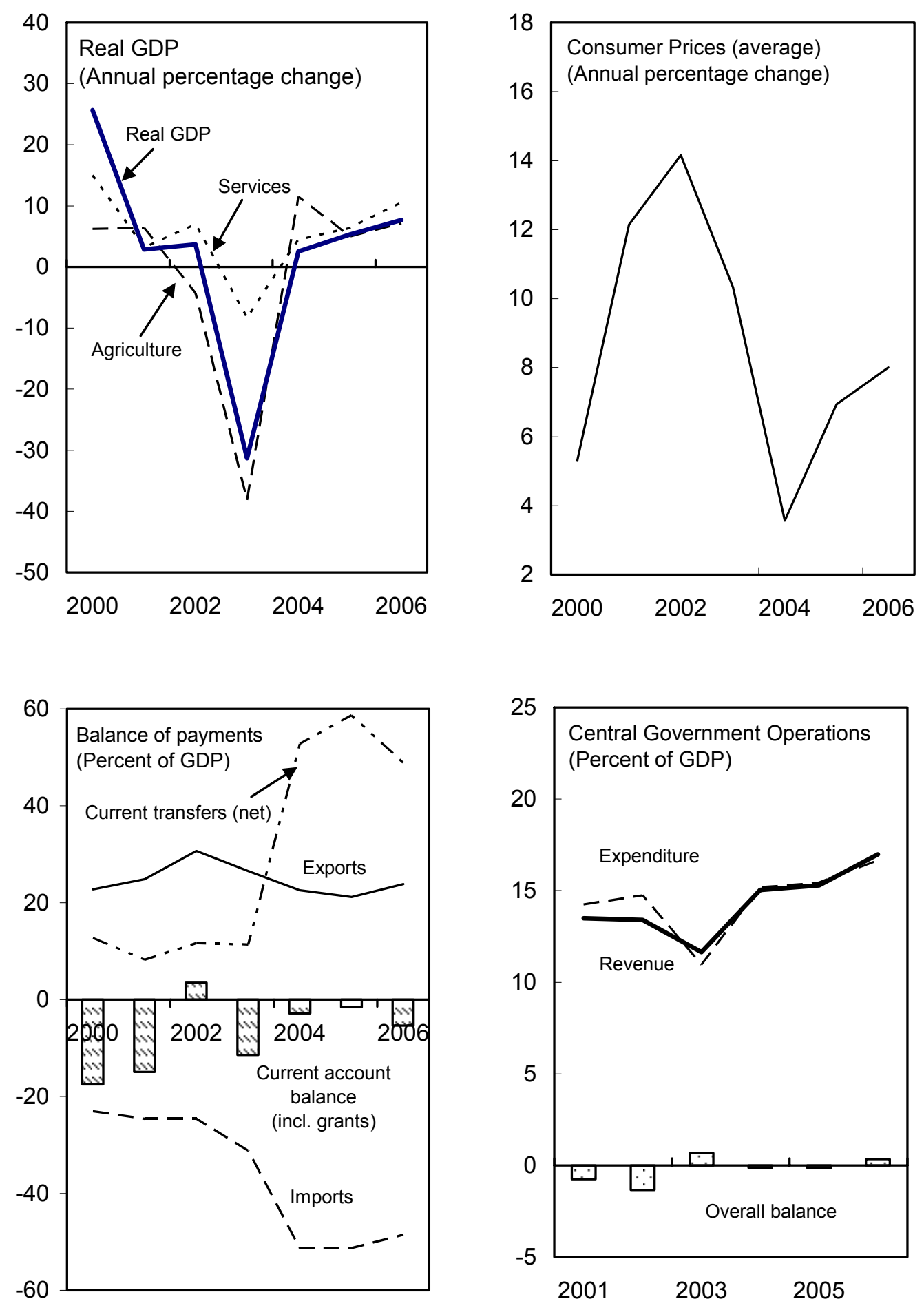

Sources: Liberian authorities; and Fund staff estimates and projections. 
Figure 1. Liberia: Selected Economic Indicators, 2000-06 (concluded)
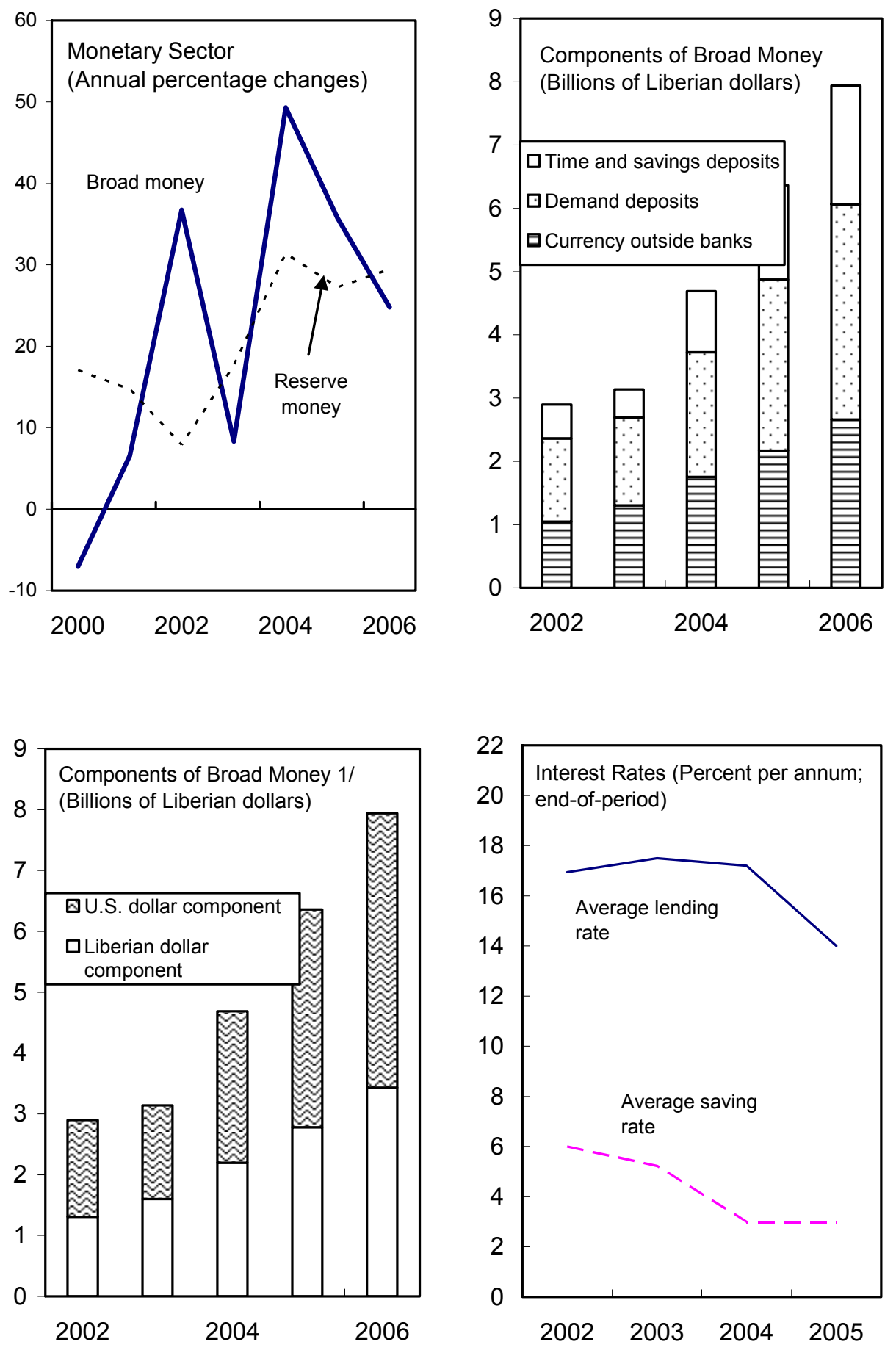

Sources: Liberian authorities; and Fund staff estimates and projections. $1 /$ Percent of total money supply. 
Figure 2. Liberia: Exchange Rates Developments, January 2000-May 2006
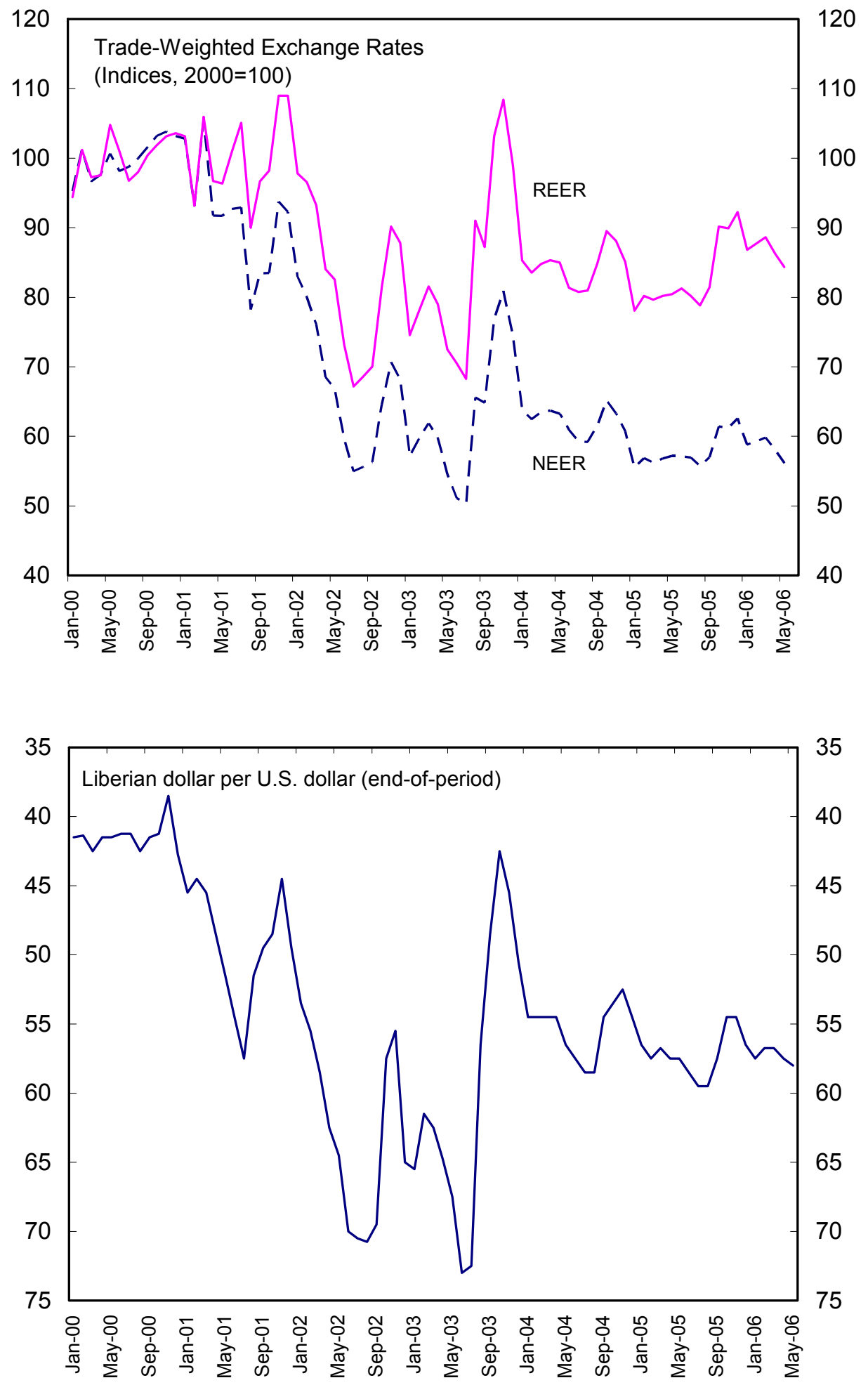

Sources: Liberian authorities; Fund staff estimates and projections. 
Table 1. Liberia: Selected Economic and Financial Indicators, 2003-2007

\begin{tabular}{|c|c|c|c|c|c|}
\hline & $\begin{array}{c}2003 \\
\text { Est. }\end{array}$ & $\begin{array}{r}2004 \\
\text { Est. }\end{array}$ & $\begin{array}{r}2005 \\
\text { Est. }\end{array}$ & $\begin{array}{c}2006 \\
\text { Proj. }\end{array}$ & $\begin{array}{l}2007 \\
\text { Proj. }\end{array}$ \\
\hline & \multicolumn{5}{|c|}{ (Annual percentage change, unless otherwise indicated) } \\
\hline \multicolumn{6}{|l|}{ National income and prices } \\
\hline Real GDP & -31.3 & 2.6 & 5.3 & 7.7 & 7.7 \\
\hline Consumer prices (annual average) $1 /$ & 10.3 & 3.6 & 6.9 & 8.0 & 7.5 \\
\hline Consumer prices (end of period) $1 /$ & 5.0 & 7.5 & 7.0 & 7.5 & 7.8 \\
\hline Nominal GDP (millions of U.S. dollars) & 410 & 460 & 530 & 661 & 725 \\
\hline GDP deflator in U.S. dollars & 10.0 & 9.3 & 9.4 & 15.8 & 1.9 \\
\hline Real GDP per capita (constant 1992 U.S. dollars) & 115 & 118 & 122 & 129 & 135 \\
\hline \multicolumn{6}{|l|}{ External sector (U.S. dollar terms) } \\
\hline Exports of goods, f.o.b. & -34.5 & -4.7 & 8.1 & 40.3 & 6.7 \\
\hline Imports of goods, f.o.b. & -4.3 & 84.4 & 15.2 & 17.9 & 12.3 \\
\hline Terms of trade (deterioration - ) & 21.1 & 4.9 & 4.2 & 31.6 & -6.1 \\
\hline Official exchange rate (L\$/US\$; end of period) & 50.5 & 54.5 & 56.5 & $\ldots$ & $\ldots$ \\
\hline Nominal effective exchange rate (end of period) & 9.1 & -18.4 & 3.1 & $\ldots$ & $\ldots$ \\
\hline Real effective exchange rate (end of period) & 12.7 & -14.0 & 8.4 & $\ldots$ & ... \\
\hline \multicolumn{6}{|l|}{ Central government operations } \\
\hline Total revenue and grants & -34.3 & 44.8 & 17.2 & 38.9 & 35.1 \\
\hline Of which : total revenue & -38.5 & 52.3 & 13.1 & 35.1 & 20.6 \\
\hline Total expenditure and net lending & -43.8 & 55.3 & 17.2 & 34.9 & 37.8 \\
\hline Of which : current expenditure & -5.6 & 144.7 & 20.6 & 31.7 & 21.3 \\
\hline capital expenditure & -62.2 & -51.9 & -3.6 & 59.2 & 141.5 \\
\hline & \multicolumn{5}{|c|}{$\begin{array}{c}\text { (Annual change; in percent of beginning-period stock of money, } \\
\text { unless otherwise indicated) }\end{array}$} \\
\hline \multicolumn{6}{|l|}{ Money and banking } \\
\hline Net foreign assets & 223.6 & -456.0 & -96.6 & -29.1 & -25.7 \\
\hline Net domestic assets & -215.3 & 505.3 & 132.4 & 53.9 & 41.4 \\
\hline Net claims on government & -320.1 & 533.5 & 133.4 & 52.3 & 44.0 \\
\hline Claims on nongovernment & -8.1 & 21.1 & 7.2 & 6.0 & 3.8 \\
\hline Other items net & 112.9 & -49.4 & -8.3 & -4.4 & -6.4 \\
\hline Broad money (M2) 2/ & 8.3 & 49.3 & 35.7 & 24.8 & 15.7 \\
\hline Velocity (GDP relative to broad money) & 6.6 & 5.3 & 4.7 & 4.8 & 4.5 \\
\hline Reserve money & 17.6 & 31.4 & 27.2 & 29.5 & 25.3 \\
\hline Broad money (stocks, billions of Liberian dollars) & 3.1 & 4.7 & 6.4 & 7.9 & 9.2 \\
\hline Liberian dollar component & 1.6 & 2.2 & 2.8 & 3.4 & 4.2 \\
\hline U.S. dollar component & 1.5 & 2.5 & 3.6 & 4.5 & 4.9 \\
\hline & \multicolumn{5}{|c|}{ (Percent of GDP) } \\
\hline \multicolumn{6}{|l|}{ Central government operations (January-December) } \\
\hline Total revenue and grants & 11.6 & 15.0 & 15.3 & 17.0 & 20.9 \\
\hline Of which : total revenue & 10.9 & 14.8 & 14.5 & 15.7 & 17.3 \\
\hline Total expenditure and net lending & 11.0 & 15.2 & 15.4 & 16.6 & 20.9 \\
\hline Of which : current expenditure & 6.0 & 13.0 & 13.6 & 14.4 & 15.9 \\
\hline capital expenditure & 5.0 & 2.1 & 1.8 & 2.3 & 5.0 \\
\hline Overall fiscal balance (cash basis) & 0.7 & -0.1 & -0.1 & 0.3 & 0.0 \\
\hline \multicolumn{6}{|l|}{ External sector } \\
\hline Current account balance, including grants (deficit, -) & -11.4 & -2.8 & -1.6 & -5.4 & -12.3 \\
\hline Of which: public interest payments due & -11.6 & -11.7 & -15.6 & -15.6 & -15.4 \\
\hline Current account balance, excluding grants (deficit, -) & -16.2 & -44.0 & -55.7 & -51.2 & -53.3 \\
\hline Trade balance (deficit, -) & -4.6 & -28.7 & -30.1 & -24.7 & -26.5 \\
\hline Exports, f.o.b. & 26.6 & 22.6 & 21.2 & 23.8 & 23.2 \\
\hline Imports, f.o.b. & -31.2 & -51.3 & -51.3 & -48.5 & -49.6 \\
\hline Public sector external debt outstanding (total) & 820 & 812 & 690 & 569 & 534 \\
\hline \multicolumn{6}{|c|}{ (Millions of U.S. dollars, unless otherwise indicated) } \\
\hline Current account balance including grants (deficit, -) & -47 & -13 & -8 & -36 & -90 \\
\hline Trade balance (deficit, -) & -19 & -132 & -160 & -163 & -192 \\
\hline CBL's net foreign exchange position & -1.3 & 3.3 & 6.5 & 19.9 & 34.9 \\
\hline (months of imports of goods and services) & -0.1 & 0.1 & 0.2 & 0.6 & 0.9 \\
\hline
\end{tabular}

Sources: Liberian authorities; and Fund staff estimates and projections.

$1 /$ Technical adjustments were made to the CPI in 2004 in light of the substitution of some items in the CPI survey in mid-2004. 2/ Defined as Liberian currrency outside banks plus demand, time, and savings deposits in Liberian and U.S. dollars. 
Table 2. Liberia: Balance of Payments, 2003-2007

\begin{tabular}{|c|c|c|c|c|c|}
\hline & $\begin{array}{c}2003 \\
\text { Est. }\end{array}$ & $\begin{array}{r}2004 \\
\text { Est. }\end{array}$ & $\begin{array}{r}2005 \\
\text { Est. }\end{array}$ & $\begin{array}{c}2006 \\
\text { Proj. }\end{array}$ & $\begin{array}{r}2007 \\
\text { Proj. }\end{array}$ \\
\hline & \multicolumn{5}{|c|}{ (Millions of U.S. dollars, unless otherwise indicated) } \\
\hline Trade balance & -19 & -132 & -160 & -163 & -192 \\
\hline Exports, f.o.b. & 109 & 104 & 112 & 157 & 168 \\
\hline Of which: rubber & 44 & 93 & 99 & 141 & 129 \\
\hline timber & 55 & 0 & 0 & 0 & 13 \\
\hline Imports, f.o.b & -128 & -236 & -272 & -321 & -360 \\
\hline Petroleum & -30 & -66 & -89 & -115 & -125 \\
\hline Rice & -39 & -34 & -30 & -30 & -34 \\
\hline Donor + FDI related & -19 & -106 & -141 & -162 & -187 \\
\hline Other & -52 & -30 & -13 & -13 & -15 \\
\hline Services (net) & -14 & -37 & -47 & -58 & -68 \\
\hline Income (net) & -60 & -87 & -113 & -136 & -147 \\
\hline Of which: public interest payments due & -47 & -54 & -82 & -103 & -111 \\
\hline Current transfers (net) & 47 & 243 & 311 & 322 & 317 \\
\hline Donor transfers (net) & 20 & 189 & 287 & 302 & 297 \\
\hline Private transfers (net) & 27 & 53 & 24 & 20 & 20 \\
\hline Current account balance & -47 & -13 & -8 & -36 & -90 \\
\hline Current account balance, excluding grants & -66 & -202 & -295 & -338 & -386 \\
\hline Capital and financial account & 0 & -9 & -43 & -90 & -43 \\
\hline Official financing & 0 & 0 & -36 & -36 & -36 \\
\hline Disbursements & 0 & 0 & 0 & 0 & 0 \\
\hline Amortization & -28 & -30 & -36 & -36 & -36 \\
\hline Private financing & 0 & -9 & -7 & -54 & -7 \\
\hline Direct foreign investment & 0 & 0 & 3 & 6 & 11 \\
\hline Other investment (incl. trade credit) & 0 & -9 & -10 & -60 & -18 \\
\hline Errors and omissions & -29 & -57 & -64 & 0 & 0 \\
\hline Overall balance & -75 & -79 & -115 & -126 & -132 \\
\hline Financing & 75 & 79 & 115 & 126 & 132 \\
\hline Change in official reserves (increase -) & 0 & -5 & -3 & -13 & -15 \\
\hline Arrears (accrual + ) 1/ & 75 & 84 & 118 & 139 & 147 \\
\hline Use of Fund credit (net change in arrears) & 8 & 10 & 17 & 17 & 17 \\
\hline Increase in non-Fund arrears & 67 & 74 & 101 & 122 & 130 \\
\hline \multicolumn{6}{|l|}{ Memorandum items: } \\
\hline \multicolumn{6}{|l|}{ Current account balance (percent of GDP): } \\
\hline Including grants & -11.4 & -2.8 & -1.6 & -5.4 & -12.3 \\
\hline Excluding grants & -16.2 & -44.0 & -55.7 & -51.2 & -53.3 \\
\hline Excluding grants and public interest payments due & -4.6 & -32.2 & -40.1 & -35.6 & -37.9 \\
\hline Trade balance (percent of GDP) & -4.6 & -28.7 & -30.1 & -24.7 & -26.5 \\
\hline \multicolumn{6}{|l|}{ Public sector external debt (medium and long term) } \\
\hline Debt outstanding, including arrears & 3,364 & 3,735 & 3,660 & 3,763 & 3,876 \\
\hline (percent of exports of goods and services) & 2,420 & 2,742 & 2,538 & 1,966 & 1,901 \\
\hline (percent of GDP) & 820 & 812 & 690 & 569 & 534 \\
\hline Debt service charges & 74.9 & 83.9 & 118.4 & 139.0 & 147.4 \\
\hline (in percent of GDP) & 18.3 & 18.3 & 22.3 & 21.0 & 20.3 \\
\hline Terms of trade $(1997=100)$ & 130.2 & 136.7 & 142.5 & 187.4 & 175.9 \\
\hline CBL's net foreign exchange position & -1 & 3 & 7 & 20 & 35 \\
\hline CBL's net foreign exchange position (in months of imports of goods and services) & -0.1 & 0.1 & 0.2 & 0.6 & 0.9 \\
\hline CBL's net foreign exchange position (in months of non-donor imports) & -0.1 & 0.2 & 0.4 & 1.0 & 1.5 \\
\hline GDP at current prices & 410 & 460 & 530 & 661 & 725 \\
\hline
\end{tabular}

Sources: Liberian authorities; and Fund staff estimates and projections.

1/ Apart from token payments to international financial institutions, Liberia is not servicing its external debt. 
Table 3. Liberia: Summary of Central Government Operations, 2002/03-2006/07

\begin{tabular}{|c|c|c|c|c|c|}
\hline & $2002 / 03$ & $2003 / 04$ & $2004 / 05$ & $2005 / 06$ & $\begin{array}{l}\text { 2006/07 } \\
\text { Proj. }\end{array}$ \\
\hline & \multicolumn{5}{|c|}{ (Millions of U.S. dollars) } \\
\hline Total revenue and grants $1 /$ & 56.6 & 58.1 & 80.3 & 89.6 & 135.9 \\
\hline Total revenue & 56.6 & 55.1 & 79.3 & 84.6 & 120.9 \\
\hline Tax revenue & 52.7 & 52.9 & 73.1 & 79.4 & 106.2 \\
\hline Maritime revenues & 11.0 & 15.5 & 10.1 & 12.1 & 11.0 \\
\hline Stumpage fees and land rental & 7.3 & 0.1 & 0.0 & 0.0 & 0.0 \\
\hline Taxes on international trade & 18.2 & 23.3 & 28.6 & 33.0 & 46.6 \\
\hline Petroleum sales tax & 4.5 & 0.8 & 1.5 & 2.1 & 6.4 \\
\hline Goods and services tax & 1.8 & 3.6 & 4.2 & 5.9 & 7.6 \\
\hline Income tax & 9.4 & 9.4 & 28.4 & 25.1 & 33.7 \\
\hline Other & 0.4 & 0.3 & 0.3 & 1.2 & 1.0 \\
\hline Nontax revenue & 3.9 & 2.2 & 6.3 & 5.2 & 14.7 \\
\hline Of which: overdue tax collection & 0.0 & 0.0 & 0.0 & 0.0 & 4.8 \\
\hline Grants & 0.0 & 3.0 & 1.0 & 5.0 & 15.0 \\
\hline Budget support & 0.0 & 3.0 & 1.0 & 1.0 & 0.0 \\
\hline Project & 0.0 & 0.0 & 0.0 & 4.0 & 15.0 \\
\hline Total expenditure and net lending (cash basis) & 69.2 & 50.6 & 77.0 & 72.2 & 153.3 \\
\hline Current expenditure & 28.3 & 46.9 & 66.3 & 65.0 & 122.5 \\
\hline Wages and salaries & 13.1 & 21.0 & 35.4 & 30.2 & 45.6 \\
\hline Goods and services & 5.9 & 19.1 & 22.9 & 19.1 & 55.8 \\
\hline Interest on debt & 8.8 & 2.8 & 2.0 & 2.7 & 2.8 \\
\hline External & 0.5 & 0.2 & 0.7 & 0.9 & 1.0 \\
\hline Domestic & 8.3 & 2.6 & 1.4 & 1.8 & 1.8 \\
\hline Domestic arrears clearance/payments & 0.0 & 0.0 & 0.0 & 5.9 & 4.0 \\
\hline Subsidies, transfers, and net lending & 0.6 & 4.0 & 6.0 & 7.1 & 14.3 \\
\hline Capital expenditure & 40.9 & 3.7 & 10.6 & 7.1 & 30.8 \\
\hline Internally financed & 40.9 & 3.7 & 10.6 & 3.1 & 15.8 \\
\hline Externally financed & 0.0 & 0.0 & 0.0 & 4.0 & 15.0 \\
\hline Statistical discrepancies & 0.0 & 0.0 & 0.0 & 0.0 & 0.0 \\
\hline Overall surplus or deficit (cash basis) & -12.6 & 7.5 & 3.4 & 17.4 & -17.4 \\
\hline Adjustment to cash basis $2 /$ & na & na & na & 17.4 & -17.4 \\
\hline \multirow[t]{2}{*}{ Overall surplus or deficit (commitment basis) } & na & na & na & 0.0 & 0.0 \\
\hline & \multicolumn{5}{|c|}{ (Percent of GDP, unless otherwise indicated) } \\
\hline Total revenue and grants & 11.9 & 13.4 & 16.2 & 15.0 & 19.6 \\
\hline Total revenue & 11.9 & 12.7 & 16.0 & 14.2 & 17.4 \\
\hline Grants & 0.0 & 0.7 & 0.2 & 0.8 & 2.2 \\
\hline Total expenditure and net lending & 14.5 & 11.6 & 15.5 & 12.1 & 22.1 \\
\hline Current expenditure & 5.9 & 10.8 & 13.4 & 10.9 & 17.6 \\
\hline Of which: wages and salaries & 2.7 & 4.8 & 7.2 & 5.1 & 6.6 \\
\hline Capital expenditure & 8.6 & 0.9 & 2.1 & 1.2 & 4.4 \\
\hline Overall surplus or deficit (incl. grants) & -2.6 & 1.7 & 0.7 & 2.9 & -2.5 \\
\hline Grants & 0.0 & 0.7 & 0.2 & 0.8 & 2.2 \\
\hline Overall surplus or deficit (excl. grants) & -2.6 & 1.0 & 0.5 & 2.1 & -4.7 \\
\hline
\end{tabular}

Sources: Liberian authorities; and Fund staff estimates and projections.

$1 / 2006 / 07$ revenue projections are GOL estimates for the budget. Expenditure projections include US $\$ 17.4$ million of commitments at end-2005/06 projected to be recorded as expenditure in 2006/07.

2/ Adjustments in 2005/06 and 2006/07 are a result of commitments at end-2005/06 projected to be recorded as expenditure in $2006 / 07$. 
Table 4. Liberia: Monetary Survey, 2003-2007

\begin{tabular}{|c|c|c|c|c|c|}
\hline & $\begin{array}{c}2003 \\
\text { Dec. }\end{array}$ & $\begin{array}{l}2004 \\
\text { Dec. }\end{array}$ & $\begin{array}{l}2005 \\
\text { Dec. }\end{array}$ & $\begin{array}{l}2006 \\
\text { Dec. } \\
\text { Proj. }\end{array}$ & $\begin{array}{r}2007 \\
\text { Dec. } \\
\text { Proj. }\end{array}$ \\
\hline & \multicolumn{5}{|c|}{ (Millions of Liberian dollars, unless otherwise indicated) } \\
\hline Net foreign assets & $-30,335$ & $-44,646$ & $-49,175$ & $-51,027$ & $-53,070$ \\
\hline Of which: Fund credit and overdue charges & $-30,579$ & $-45,998$ & $-51,422$ & $-53,478$ & $-55,618$ \\
\hline Of which: CBL's gross foreign reserves & 370 & 1,019 & 1,432 & 2,389 & 3,365 \\
\hline assets corresponding to Government U.S. dollar denominated deposits at CBL & 304 & 107 & 70 & 0 & 0 \\
\hline assets corresponding to commercial banks' U.S. dollar deposits at CBL & 131 & 730 & 993 & 1,251 & 1,373 \\
\hline CBL's net foreign exchange position & -64 & 182 & 370 & 1,138 & 1,992 \\
\hline Net domestic assets & 33,473 & 49,333 & 55,537 & 58,967 & 62,256 \\
\hline Net domestic credit & 45,594 & 63,003 & 69,593 & 73,305 & 77,099 \\
\hline Net claims on government & 43,597 & 60,343 & 66,594 & 69,923 & 73,420 \\
\hline Of which: Fund credit and overdue charges & 30,579 & 45,998 & 51,422 & 53,478 & 55,618 \\
\hline Claims on private sector & 1,136 & 1,651 & 2,064 & 3,062 & 3,360 \\
\hline Claims on public enterprises & 59 & 106 & 83 & 210 & 210 \\
\hline Claims on nonbank financial institutions & 86 & 187 & 110 & 110 & 110 \\
\hline Claims on non-government & 1,997 & 2,660 & 2,999 & 3,381 & 3,679 \\
\hline Other items, net & $-12,120$ & $-13,669$ & $-14,056$ & $-14,337$ & $-14,843$ \\
\hline \multicolumn{6}{|l|}{ Monetary aggregates } \\
\hline Currency outside banks (Liberian banknotes and coins only) & 1,304 & 1,755 & 2,169 & 2,659 & 3,391 \\
\hline Commercial banks' reserves at CBL $1 /$ & 152 & 142 & 230 & 423 & 464 \\
\hline Of which: required reserves & 132 & 111 & 155 & 170 & 186 \\
\hline Reserve Money (in billions of Liberian dollars) $2 /$ & 1,561 & 2,050 & 2,609 & 3,378 & 4,232 \\
\hline Commercial bank deposits $3 /$ & 1,835 & 2,932 & 4,193 & 5,281 & 5,795 \\
\hline Total demand deposits & 1,391 & 1,972 & 2,702 & 3,403 & 3,734 \\
\hline Liberian dollar denominated deposits & 137 & 184 & 221 & 278 & 305 \\
\hline U.S. dollar denominated deposits & 1,254 & 1,788 & 2,481 & 3,125 & 3,430 \\
\hline Time, savings, and other deposits & 444 & 960 & 1,491 & 1,878 & 2,061 \\
\hline Liberian dollar denominated deposits & 160 & 260 & 392 & 493 & 541 \\
\hline U.S. dollar denominated deposits & 284 & 700 & 1,099 & 1,384 & 1,519 \\
\hline Broad money (M2) 4/ & 3,139 & 4,687 & 6,362 & 7,940 & 9,186 \\
\hline Liberian dollar component & 1,601 & 2,199 & 2,781 & 3,431 & 4,237 \\
\hline U.S. dollar component & 1,538 & 2,488 & 3,581 & 4,510 & 4,949 \\
\hline \multicolumn{6}{|l|}{ Memorandum items: } \\
\hline U.S. dollar component broad money (excluding banknotes, in millions of U.S. dollars) & 30.5 & 45.7 & 63.4 & 79.0 & 86.7 \\
\hline U.S. dollar component of broad money (percent of broad money, excluding banknotes) & 49.0 & 53.1 & 56.3 & 56.8 & 53.9 \\
\hline U.S. dollar denominated demand deposits (millions of U.S. dollars) & 24.8 & 32.8 & 43.9 & 54.7 & 60.1 \\
\hline U.S. dollar denominated time, saving, and other deposits (millions of U.S. dollars) & 5.6 & 12.8 & 19.5 & 24.2 & 26.6 \\
\hline Broad money (annual change) & 8.3 & 49.3 & 35.7 & 24.8 & 15.7 \\
\hline Liberian dollar component broad money (percent of beginning period broad money) & 10.1 & 19.0 & 12.4 & 10.2 & 10.2 \\
\hline U.S. dollar component broad money (percent of beginning period broad money) & -1.8 & 30.3 & 23.3 & 14.6 & 5.5 \\
\hline CBL's net foreign exchange position (millions of U.S. dollars) & -1.3 & 3.3 & 6.5 & 19.9 & 34.9 \\
\hline Money Multiplier & 2.0 & 2.3 & 2.4 & 2.4 & 2.2 \\
\hline Velocity (GDP relative to broad money) & 6.6 & 5.3 & 4.7 & 4.8 & 4.5 \\
\hline Currency/deposits (percent; Liberian dollars only) & 554 & 395 & 354 & 345 & 401 \\
\hline Nominal GDP (millions of Liberian dollars; annualized basis) & 20,717 & 25,069 & 29,958 & 37,730 & 41,407 \\
\hline
\end{tabular}

Sources: Liberian authorities; and Fund staff estimates and projections.

1/ Derived from commercial banks' balance sheets (Liberian dollar denominated)

2/ Liberian dollar currency outside banks and commercial banks reserves (Liberian dollar denominated) held at central bank.

3/ One bank has been excluded from the deposit since May 2003.

4/ Excluding U.S. dollars in circulation. 
Table 5. Liberia: Medium-Term Scenarios, 2006-11

(Percent of GDP, unless otherwise indicated)

\begin{tabular}{|c|c|c|c|c|c|c|}
\hline & 2006 & 2007 & 2008 & 2009 & 2010 & 2011 \\
\hline \multicolumn{7}{|l|}{ Baseline scenario ${ }^{1 /}$} \\
\hline Real GDP growth (percent) & 7.7 & 7.7 & 8.1 & 8.2 & 9.4 & 10.5 \\
\hline Consumer price index (percent, annual average) & 8.0 & 7.5 & 7.0 & 6.5 & 6.0 & 5.0 \\
\hline Fiscal balance (including grants) & 0.3 & 0.0 & 0.0 & 0.0 & 0.0 & 0.0 \\
\hline Fiscal revenues (including grants) & 17.0 & 20.9 & 22.3 & 22.6 & 22.7 & 22.9 \\
\hline Of which: grants ${ }^{2 /}$ & 1.3 & 3.6 & 5.0 & 5.2 & 5.3 & 5.5 \\
\hline Current account balance (excl. grants) & -51.2 & -53.3 & -53.1 & -49.6 & -45.1 & -35.3 \\
\hline Grants (donor transfers, net) & 45.8 & 40.9 & 37.4 & 34.1 & 30.1 & 28.2 \\
\hline Net official reserves (millions of U.S. dollars) & 19.9 & 34.9 & 49.9 & 64.8 & 79.8 & 95.7 \\
\hline Real GDP per capita (U.S. dollars, 1992 prices) & 129 & 135 & 143 & 151 & 161 & 174 \\
\hline \multicolumn{7}{|l|}{ Lower-case scenario $^{3 /}$} \\
\hline Real GDP growth (percent) & 7.7 & 3.8 & 3.8 & 4.4 & 5.8 & 5.6 \\
\hline Consumer price index (percent, annual average) & 8.0 & 6.5 & 6.0 & 5.5 & 5.0 & 5.0 \\
\hline Fiscal balance (including grants) & 0.3 & 0.0 & 0.0 & 0.0 & 0.0 & 0.0 \\
\hline Fiscal revenues (including grants) & 17.0 & 17.9 & 19.0 & 19.0 & 19.1 & 19.1 \\
\hline Of which: grants ${ }^{4 /}$ & 1.3 & 2.4 & 3.4 & 3.5 & 3.5 & 3.6 \\
\hline Current account balance (excl. grants) & -51.2 & -52.5 & -54.8 & -52.9 & -48.0 & -40.8 \\
\hline Grant (donor transfers, net) & 45.8 & 30.0 & 27.7 & 25.4 & 22.0 & 21.1 \\
\hline Net official reserves (millions of U.S. dollars) & 19.9 & 32.9 & 45.9 & 58.8 & 71.8 & 84.7 \\
\hline Real GDP per capita (U.S. dollars) & 129 & 130 & 132 & 135 & 139 & 144 \\
\hline
\end{tabular}

Sources: Liberian authorities; and IMF staff estimates and projections.

1/ This scenario is based on prudent macroeconomic and reform policies, with effective implementation of the GEMAP.

2/ A steady rise is assumed for donor inflows at about half the rate of nominal GDP growth, based on the country's extensive reconstruction needs and assumed strong policy performance that would likely elicit continued strong donor support.

$3 /$ This scenario is based on a slower pace of reform, with consequently lower levels of donor support.

4/ Based on weaker policy reform, donor inflows are assumed to equal about two-thirds of those in the baseline scenario. 


\section{Appendix I. Liberia - Letter of Intent}

September 12, 2006

Mr. Rodrigo de Rato

Managing Director

International Monetary Fund

Washington, D.C. 20431

USA

Dear Mr. de Rato,

1. We would like to take this opportunity to inform you of our progress in implementing Liberia's staff-monitored program (SMP) that was agreed with IMF staff in February and approved by you in April. You will recall that, after decades of mismanagement and internal conflict that have left the Liberian economy in ruins and the vast majority of the population desperately poor, the SMP's key objectives are to rebuild public institutions, restore credible financial management, and accelerate structural reforms to bring hope and confidence back to the country. To this end, the program is based on ambitious macroeconomic policy and structural reform targets.

2. We believe we have made good progress in implementing our economic program, notwithstanding even more serious capacity constraints than we foresaw in the first weeks of the new administration and the need to reach agreement with the opposition-led legislature on some key measures. We have greatly strengthened fiscal management and made significant advances on our structural reform agenda. The SMP's quantitative benchmarks through end-June were met (Table 1A), as were most of the structural benchmarks, with some encountering temporary delays (Table 2). We are taking corrective action to ensure that these benchmarks are also met. As stipulated under the SMP, we submitted a balanced budget proposal for the 2006/07 fiscal year to the legislature on June 29. The legislature approved the budget on August 22.

3. This critical break with the past and our resolute commitment to push our reform agenda ahead with the support of the international community offer the promise of sustained growth for Liberia over the medium term and the alleviation of the suffering of the Liberian people going forward.

4. Since February, revenue performance has improved dramatically, due, in part, to the more comprehensive implementation of pre-shipment inspections of all imports and exports, a strengthening of the Large Tax Payer Unit (LTU) (a benchmark for end-March), and the elimination of noncash methods for the settlement of tax obligations. Overall, revenues for 
the period February-June 2006 rose 18 percent over the corresponding period the year before, and exceeded the program floor by a comfortable margin. While the number of tax payers covered by the LTU fell short of the end-June benchmark, we are in the process of auditing a number of companies and expect to meet the target by end-September 2006. We recognize, however, that a reorganization and further strengthening of the LTU is needed and, following an audit of the unit by the Auditor General, are now considering additional changes in the broader context of a review of revenue administration on the basis of technical assistance from the Fiscal Affairs Department of the IMF.

5. We also developed a strategy to deal with overdue tax obligations (a benchmark for end-June). This entailed the identification of businesses with overdue obligations, the amounts involved, the period covered, and reasons for delayed settlement. Notifications for payment have been sent. In the event a business persists in its failure to settle overdue obligations, it will be sent warning notices calling for payment within a reasonable timeframe as allowed by the Liberian Revenue Code, or face closure in line with remedies provided by the Code.

6. In line with our commitment under the SMP to implement a balanced cash-based budget and avoid the accumulation of further domestic arrears, we have strengthened the role of the Cash Management Committee, a crucial element of our commitment control system. This has been achieved by ensuring that the Bureau of the Budget does not make allotments that exceed revenues and that line ministries do not make commitments that exceed their allotments. We have also made a public announcement that, to be valid, all government purchase orders must be stamped with a special seal from the Bureau of General Accounting (a continuous benchmark from end-June). Delays in approval of the recast budget until April and the strict implementation of the new interim financial rules and enforcement of the provisions of the Public Procurement and Concessions Act led to slower than expected expenditure approval during February-April and caused the accumulation of central bank balances in the government's accounts at the Central Bank of Liberia (CBL). In May and June, we were able to execute a large volume of expenditures, bringing overall spending in February-June into line with the recast budget, without breaching the requirements of the commitment control system. In our view, following a number of workshops, the ability to execute spending in June reflects the increased familiarity of line ministries with the proper procedures for submitting expenditure requests. We recognize the importance of prioritized monthly cash plans for keeping expenditures in line with revenues and will, therefore, strictly adhere to them in the 2006/07 fiscal year. We fully expect expenditure plans to be executed in a more timely fashion in the period ahead.

7. Going beyond understandings in the SMP, we have submitted legislation that would prevent the executive from making changes to budget allocations exceeding 30 percent of a ministry's or agency's approved budget without the approval of the legislature. We have also submitted to the legislature draft legislation to allow for the full integration of the Bureau of 
Budget and the Bureau of Maritime Affairs into the Ministry of Finance. To facilitate the timely approval of the budget, we chose not to submit this legislation to the legislature until after the passage of the 2006/07 budget. However, the intent and spirit of the integration have been met - in February, the President instructed the heads of these agencies to report directly to the Minister of Finance, thus adhering to the substance of the draft legislation. This has improved budget execution as well as the budget formulation process.

8. The verification of the stock of the government's domestic debt (a benchmark for end-June) has proved to be a more challenging task than we envisaged. We judged it necessary to appoint an interministerial vetting committee to verify smaller claims and selected, through international tender, an external auditor to verify the larger claims. We recognize that the verification of the stock of outstanding claims is a crucial first step toward finalizing our domestic debt resolution strategy by end-September. We are, therefore, pushing for the verification process to be completed as soon as possible. In addition to the verification of smaller claims on the government, the interministerial committee will provide input into the task of designing the domestic debt resolution strategy and developing a debt management policy for the government.

9. Monetary policy has been effective in maintaining inflation in single digits. In view of the high dollarization of the economy, the expansion of the Liberian component of money supply will continue to be limited to maintain a broadly stable exchange rate, while meeting the reserve accumulation targets under the SMP. The CBL has held regular foreign exchange auctions since end-March (a continuous benchmark from end-March), which have contributed to the maintenance of the relative stability of the exchange rate. The foreign exchange market remains the main channel through which monetary impulses affect prices, and the exchange rate continues to be the most meaningful indicator of monetary policy conditions. The monetary policy framework has been improved by clarifying the role of the Money Management and Policy Review Committee (a continuous benchmark from endMarch) and the posting of the final monetary policy framework paper on the CBL website (a benchmark for end-March) in March. Financial management at the CBL has been strengthened significantly, and the CBL will continue to target a balanced cash-based budget in line with its commitment under the SMP. Moreover, a financial restructuring plan for the CBL will be completed by end-September 2006, while an external audit of the CBL ( a benchmark for end-September) will be undertaken in early October. We have also requested a voluntary safeguards assessment in anticipation of a Fund-supported program.

10. We have taken important steps to improve governance that are consistent with the donor-supported Governance and Economic Management Assistance Program (GEMAP) and the SMP. In particular, internationally recruited experts with co-signatory authority have been placed at the main revenue generating agencies and a Fund-recruited expert, working under the guidance of the Executive Governor, has been serving as Chief Administrator at the CBL since February. A program for reviewing all concessions, contracts, and licenses 
granted under the previous transitional government (a benchmark for end-April) was approved by the steering committee of the GEMAP in May. This review, which is now under way, is likely to be completed only by the end of the year, due to delays in appointing internationally recruited experts. We expect, however, that the review of the most important contracts (e.g. MITTAL Steel and Firestone) will be completed by end-September 2006. A new travel ordinance, incorporating the main recommendations of the ECOWAS-financed audit report, was issued on April 1 (a benchmark for end-March). Substantial progress has been made in developing a national anti-corruption strategy (a benchmark for end-May). A draft anti-corruption policy paper that lays out the main elements of an anti-corruption strategy has been completed and is being reviewed in consultation with donors. Following approval by the President, the EGSC and the LRDC, the strategy will be finalized by endSeptember 2006. In the meantime, legislative ratification of the anticorruption conventions of the United Nations and African Union have been obtained. The government has also implemented a number of anti-corruption measures, including requiring incoming ministers to declare their assets, drafting a code of conduct for the civil service, publishing an ECOWAS audit of the previous government, and preparing for judicial action against officials named in that audit.

11. We are pleased to report that good progress has been made in preparing an Interim Poverty Reduction Strategy Paper (I-PRSP). A draft I-PRSP has been completed and is being finalized in consultation with stakeholders and development partners. In line with our commitment expressed to you in April, we expect to be able to send the final I-PRSP document to the IMF and World Bank by end-September 2006.

12. The 2006/07 budget targets a cash balance, recognizing that any loan financing, whether external or domestic, will be imprudent for some time to come. The budget targets an increase in revenues of 43 percent over the 2005/06 fiscal year. While ambitious, we believe that this target is attainable, based on revenue performance during the last five months of the previous fiscal year and the significant further strengthening of revenue administration that we intend to implement. In order to broaden the revenue base, we also plan to eliminate some tax and tariff exemptions. Moreover, we expect to see benefits from a safer and more enabling security and business environment. We have also sought to enhance the poverty reduction impact of government expenditures. Thus, the budget for the social services subsector, which includes education and health care, has been increased by 56 percent, to a quarter of all government expenditure. Also, spending on community services and rural development, including agriculture and forestry, are slated to increase by 183 percent and 278 percent, respectively. We fully recognize that a strong domestic revenue mobilization effort is crucial to providing much needed additional resources to address Liberia's numerous poverty and development challenges. Moreover, we acknowledge the uncertainty about government revenues and the importance of implementing prioritized expenditure plans to ensure that appropriate adjustments to expenditures can be made, should the need arise. 
13. In consultation with IMF staff, we have modified the end-September 2006 quantitative benchmarks of the SMP and developed preliminary quarterly benchmarks for the remainder of the 2006/07 fiscal year that are consistent with the 2006/07 budget (Table 1B). Regarding the latter, it is our hope that these can be established as quantitative performance criteria under a rights accumulation program (RAP) that would succeed the SMP.

14. In June, the U.N. Security Council provisionally lifted sanctions on the export of timber from Liberia in recognition of our efforts to strengthen the management of forestry resources. Progress has also been made in making Liberia compliant with the Kimberley Process Certification Scheme, which should lead to the lifting of sanctions on diamond exports. We see the lifting of these sanctions and our performance under the SMP and the GEMAP as providing a foundation for the restoration of stability and growth, but recognize that deeper reforms are needed to sustain progress. Implementation of a solid macroeconomic framework under the SMP has already yielded substantial benefits in terms of improved fiscal performance and structural reforms, and ongoing Fund technical assistance provides important policy recommendations for both the short and medium-term. Liberia faces immense economic challenges and we remain committed to implementing the necessary reforms to continue on the path of economic recovery and poverty reduction.

15. We are working with our development partners on programs to address the government's crippling capacity constraints, including the concept of a Senior Executive Service to fill technical needs below the ministerial level. In the longer term, we expect that our efforts to reform the civil service will further enhance the capacity of the government to effectively implement its policies.

16. It is our view that, under the SMP, Liberia has demonstrated a credible strengthening of its cooperation with the IMF on economic policies. We also continue to meet our monthly payment commitments. Going forward, we remain strongly committed to further improving our cooperation with the IMF with a view to resolving our arrears to the IMF and obtaining comprehensive relief on our unsustainable external debt as soon as possible. Against this background, we request that the IMF consider initiating the process of de-escalation of the remedial measures that are being applied against Liberia. The initiation of this process would provide an important confirmation to the long-suffering Liberian people and the international community that Liberia has indeed begun to turn the corner.

Sincerely yours,

$/ \mathrm{s} /$

Antoinette M. Sayeh

Minister of Finance
$/ \mathrm{s} /$

J. Mills Jones

Governor of the CBL 
Table 1A. Liberia: Quantitative Indicators (flow basis)

(Millions of US\$)

\begin{tabular}{|c|c|c|c|c|c|c|}
\hline & \multirow{2}{*}{$\begin{array}{l}\text { Jan. } 06 \\
\text { Act. }\end{array}$} & \multicolumn{2}{|c|}{ Feb.-Mar.06 } & \multicolumn{2}{|c|}{ Apr.-Jun.06 } & \multirow{2}{*}{$\begin{array}{l}\text { Jul.-Sep.06 } \\
\text { Orig. Prog. }\end{array}$} \\
\hline & & Prog. & Act. & Prog. & Act. & \\
\hline \multicolumn{7}{|l|}{ Fiscal } \\
\hline Floor on revenue collections & 8.1 & 14.1 & 18.1 & 24.7 & 27.0 & 20.3 \\
\hline Floor on cash-based fiscal balance ${ }^{1 /}$ & 5.2 & 0.0 & 9.7 & 0.0 & 4.7 & 0.0 \\
\hline Ceiling on new noncash tax/duty payment & n.a. & 0.0 & 0.0 & 0.0 & 0.0 & 0.0 \\
\hline Ceiling on new domestic borrowing & 0.0 & 0.0 & 0.0 & 0.0 & 0.0 & 0.0 \\
\hline Ceiling on new external borrowing & 0.0 & 0.0 & 0.0 & 0.0 & 0.0 & 0.0 \\
\hline \multirow{2}{*}{$\begin{array}{l}\text { Ceiling on new domestic arrears/payables (excluding the } \\
\text { arrears arising from the current debt outstanding) }\end{array}$} & n.a. & 0.0 & 0.0 & 0.0 & 0.0 & 0.0 \\
\hline & 0.0 & 0.0 & 0.0 & 0.0 & 0.0 & 0.0 \\
\hline \multicolumn{7}{|l|}{ CBL } \\
\hline Ceiling on expenses & 1.5 & 0.9 & 0.6 & 2.2 & 0.5 & 0.9 \\
\hline Ceiling on payments arrears & n.a. & 0.0 & 0.0 & 0.0 & 0.0 & 0.0 \\
\hline Floor on CBL's cash-based budget balance & -1.3 & -0.3 & 0.0 & -1.2 & 0.8 & 0.1 \\
\hline Floor on the changes in CBL's net foreign exchange position & -0.8 & 0.2 & 3.5 & 1.8 & 4.4 & 3.1 \\
\hline \multicolumn{7}{|l|}{ Other } \\
\hline Floor on token payments to the Fund (in US\$) & 60,000 & 120,000 & 120,000 & 180,000 & 180,000 & 180,000 \\
\hline
\end{tabular}

$1 /$ The fiscal balance, on a cash basis, is defined as the difference between (a) total central government revenue plus budget support (excluding project grants), and (b) total current expenditure plus investment expenditure (excluding foreign-financed investment expenditure). 
Table 1B. Liberia: Quantitative Indicators 2006/07 (cumulative basis, unless otherwise noted)

(Millions of U.S. dollars)

\begin{tabular}{|c|c|c|c|c|c|c|}
\hline & \multirow{2}{*}{$\begin{array}{c}\text { Jun. } 06^{2 /} \\
\text { Act. }\end{array}$} & \multicolumn{2}{|c|}{ Sep. 06} & \multirow{2}{*}{$\begin{array}{l}\text { Dec. } 06 \\
\text { Prel. Proj. }\end{array}$} & \multirow{2}{*}{$\begin{array}{l}\text { Mar. } 07 \\
\text { Prel. Proj. }\end{array}$} & \multirow{2}{*}{$\begin{array}{l}\text { Jun. } 07 \\
\text { Prel. Proj. }\end{array}$} \\
\hline & & Orig. Prog. & Rev. Prog. & & & \\
\hline \multicolumn{7}{|l|}{ Fiscal } \\
\hline Floor on revenue collections & 84.6 & 20.3 & 24.7 & 50.9 & 84.5 & 120.9 \\
\hline Floor on cash-based fiscal balance ${ }^{1 /}$ & 19.5 & 0.0 & -19.5 & -19.5 & -19.5 & -19.5 \\
\hline Ceiling on new noncash tax/duty payment (continuous basis) & 0.0 & 0.0 & 0.0 & 0.0 & 0.0 & 0.0 \\
\hline Ceiling on new domestic borrowing (continuous basis) & 0.0 & 0.0 & 0.0 & 0.0 & 0.0 & 0.0 \\
\hline Ceiling on new external borrowing (continuous basis) & 0.0 & 0.0 & 0.0 & 0.0 & 0.0 & 0.0 \\
\hline $\begin{array}{l}\text { Ceiling on new domestic arrears/payables (excluding the arrears } \\
\text { arising from the current debt outstanding) (continuous basis) }\end{array}$ & 0.0 & 0.0 & 0.0 & 0.0 & 0.0 & 0.0 \\
\hline \multicolumn{7}{|l|}{$\mathrm{CBL}^{3 /}$} \\
\hline Ceiling on expenses & 2.6 & 3.6 & 5.0 & 6.0 & $\cdots$ & $\cdots$ \\
\hline Ceiling on payments arrears (continuous basis) & 0.0 & 0.0 & 0.0 & 0.0 & $\cdots$ & $\ldots$ \\
\hline Floor on CBL's cash-based budget balance & -0.4 & -0.4 & -1.8 & -1.9 & $\ldots$ & $\ldots$ \\
\hline Floor on the CBL's net foreign exchange position & 13.6 & 16.7 & 16.1 & 19.9 & $\ldots$ & $\cdots$ \\
\hline \multicolumn{7}{|l|}{ Other } \\
\hline Floor on token payments to the Fund (in US\$) (continuous basis) & 680,000 & 180,000 & 180,000 & 360,000 & 540,000 & 720,000 \\
\hline
\end{tabular}

$1 /$ The fiscal balance, on a cash basis, is defined as the difference between (a) total central government revenue plus budget support (excluding project grants) and (b) total current expenditure plus investment expenditure (excluding foreign-financed investment expenditure).

$2 /$ The floor on revenue collections is total revenue for 2005/06 and the floor on cash-based fiscal balance is accumulated government surpluses at the CBL as of end-June. Most of the latter amount respresents checks approved by the CMCo prior to end-2005/06 which were not cashed prior to end-2005/06. After taking into account commitments made, but not cashed, the balance of the government account at the CBL at end-June 2006 was $\$ 2.1$ million. Under the cash-based budget, these are recorded as expenditures when they are cashed at the CBL. All CBL data are Jan.-Jun. 2006.

3/ The original program data for September 2006 reflects actual outturn at end-June, plus the original flow targets for September. 
Table 2. SMP for February-September 2006-Structural Benchmarks

\begin{tabular}{|c|c|c|}
\hline Measures & Target dates & Status \\
\hline Fiscal Management & & \\
\hline Strengthen the Large Taxpayer Unit (LTU) & End-March 2006 & Done \\
\hline $\begin{array}{l}\text { - Create a large taxpayer audit unit inside the } \\
\text { LTU with reallocation of staff within MoF }\end{array}$ & & \\
\hline $\begin{array}{l}\text { - Introduce a monthly information exchange to } \\
\text { the LTU from BIVAC }\end{array}$ & & \\
\hline $\begin{array}{l}\text { Increase the number of large taxpayers from } 60 \text { to } \\
110 \text { by auditing hidden taxpayers and/or lowering } \\
\text { the threshold value }\end{array}$ & End-June 2006 & $\begin{array}{l}\text { Ongoing - expected to be completed by } \\
\text { end-September }\end{array}$ \\
\hline $\begin{array}{l}\text { Develop a timetable to ensure approval of the } \\
2006 / 07 \text { budget }\end{array}$ & End-March 2006 & Done \\
\hline $\begin{array}{l}\text { Submit budget for legislative approval prior to } \\
\text { commencement of fiscal year }\end{array}$ & End-June 2006 & Done \\
\hline $\begin{array}{l}\text { Develop a strategy to deal with overdue tax } \\
\text { obligations }\end{array}$ & End-June 2006 & Done \\
\hline $\begin{array}{l}\text { Implement an interim commitment control system in } \\
\text { accordance with FAD TA recommendations: }\end{array}$ & $\begin{array}{l}\text { Continuous from } \\
\text { end-June } 2006\end{array}$ & $\begin{array}{l}\text { Ongoing - expected to become effective } \\
\text { after approval of the } 2006 / 07 \text { budget }\end{array}$ \\
\hline $\begin{array}{l}\text { - The Bureau of the Budget to only allocate to } \\
\text { line ministries in line with monthly cash plans }\end{array}$ & & \\
\hline $\begin{array}{l}\text { - The line ministries to ensure that their } \\
\text { commitments do not exceed allotments }\end{array}$ & & \\
\hline $\begin{array}{l}\text { - The MoF to issue a public announcement that } \\
\text { only purchase orders with the Bureau of General } \\
\text { Accounting's special seal would be valid }\end{array}$ & & \\
\hline $\begin{array}{l}\text { Integrate the Bureau of the Budget and the Bureau } \\
\text { of Maritime Affairs into the Ministry of Finance }\end{array}$ & End-June 2006 & $\begin{array}{l}\text { Ongoing - legislation expected to be } \\
\text { submitted after approval of the } 2006 / 07 \\
\text { budget }\end{array}$ \\
\hline $\begin{array}{l}\text { Establish the stock of domestic debt of the GOL, } \\
\text { and complete the verification process }\end{array}$ & End-June 2006 & $\begin{array}{l}\text { Ongoing - expected to be completed by } \\
\text { end-September }\end{array}$ \\
\hline $\begin{array}{l}\text { Finalize the domestic debt resolution strategy, } \\
\text { consistent with a restructuring plan for the CBL }\end{array}$ & $\begin{array}{l}\text { End-September } \\
2006\end{array}$ & \\
\hline
\end{tabular}


Table 2. SMP for February-September 2006—Structural Benchmarks (cont.)

\begin{tabular}{|c|c|c|}
\hline Measures & Target dates & Status \\
\hline \multicolumn{3}{|l|}{ CBL operations } \\
\hline $\begin{array}{l}\text { Revise the terms of reference for the money } \\
\text { management committee to reflect the new } \\
\text { responsibility of monetary policy, and ensure the } \\
\text { committee operates in accordance with its ToR }\end{array}$ & $\begin{array}{l}\text { Continuous } \\
\text { from end-March } \\
2006\end{array}$ & Done \\
\hline $\begin{array}{l}\text { Publicize the final Monetary Policy Framework } \\
\text { paper on the CBL website }\end{array}$ & $\begin{array}{l}\text { End-March } \\
2006\end{array}$ & Done \\
\hline $\begin{array}{l}\text { Formulate a financial restructuring plan for CBL in } \\
\text { collaboration with GOL, supported by IMF TA } \\
\text { experts }\end{array}$ & $\begin{array}{l}\text { End-September } \\
2006\end{array}$ & \\
\hline $\begin{array}{l}\text { Hold regular weekly or biweekly foreign exchange } \\
\text { auctions }\end{array}$ & $\begin{array}{l}\text { Continuous } \\
\text { from end-March } \\
2006\end{array}$ & Done \\
\hline $\begin{array}{l}\text { Conduct an external audit of the CBL by auditors of } \\
\text { international reputation }\end{array}$ & $\begin{array}{l}\text { End-September } \\
2006\end{array}$ & \\
\hline \multicolumn{3}{|l|}{ Governance and other issues } \\
\hline $\begin{array}{l}\text { Finalize the program for prioritizing and reviewing } \\
\text { all concessions, contracts, and licenses granted } \\
\text { under NTGL, and identify associated revenue flows, } \\
\text { with assistance provided by international partners }\end{array}$ & End-April 2006 & $\begin{array}{l}\text { Done, approved by EGSC in early May } \\
2006\end{array}$ \\
\hline $\begin{array}{l}\text { Complete review of concessions, contracts, and } \\
\text { licenses granted under the NTGL, with assistance } \\
\text { provided by international partners }\end{array}$ & $\begin{array}{l}\text { End-September } \\
2006\end{array}$ & \\
\hline $\begin{array}{l}\text { Implement recommendations of audit of travel } \\
\text { expenses, including revision of policy on travel } \\
\text { allowances }\end{array}$ & $\begin{array}{l}\text { Continuous } \\
\text { from end-March } \\
2006\end{array}$ & Done, issued on April 1, 2006 \\
\hline $\begin{array}{l}\text { Develop a national anti-corruption strategy for the } \\
\text { GOL, including a policy matrix for implementation, } \\
\text { with assistance provided by international partners }\end{array}$ & End-May 2006 & $\begin{array}{l}\text { Ongoing - expected to be completed by } \\
\text { end-September }\end{array}$ \\
\hline $\begin{array}{l}\text { Post on MoF's website complete financial } \\
\text { statements of revenue-generating agencies (National } \\
\text { Ports Authority, Roberts International Airport, } \\
\text { Liberian Petroleum Refining Corporation, Forestry } \\
\text { Development Authority, and Bureau of Maritime } \\
\text { Affairs), endorsed by financial controllers }\end{array}$ & $\begin{array}{l}\text { End-September } \\
2006\end{array}$ & \\
\hline $\begin{array}{l}\text { Submit a status report, endorsed by the Economic } \\
\text { Governance Steering Committee, on implementation } \\
\text { of the Governance and Economic Management } \\
\text { Assistance Program }\end{array}$ & $\begin{array}{l}\text { End-September } \\
2006\end{array}$ & \\
\hline
\end{tabular}




\section{Appendix II. Liberia-Relations with the Fund}

(As of July 31, 2006)

I. Membership Status: Joined 03/28/1962; Article XIV

II. General Resources Account:

Quota

Fund holdings of currency

Reserve position in Fund

III. SDR Department:

Net cumulative allocation

Holdings

IV. Outstanding Purchases and Loans:

Stand-By Arrangements

Contingency and Compensatory

Trust Fund
SDR Million

71.3

271.8

0.0

SDR Million

21.0

0.0

SDR Million

165.8

34.7

22.9
\% Quota

100.0

381.2

0.0

\% Allocation

100.0

0.0

\section{\% Quota}

232.5

48.7

32.1

\section{Latest Financial Arrangements:}

\begin{tabular}{|c|c|c|c|c|}
\hline Type & $\begin{array}{r}\text { Approval } \\
\text { Date }\end{array}$ & $\begin{array}{r}\text { Expira- } \\
\text { tion } \\
\text { Date } \\
\end{array}$ & $\begin{array}{c}\text { Amount } \\
\text { Approved } \\
\text { (SDR Million) }\end{array}$ & $\begin{array}{r}\text { Amount } \\
\text { Drawn } \\
\text { (SDR Million) } \\
\end{array}$ \\
\hline Stand-By & $12 / 07 / 1984$ & $12 / 06 / 1985$ & 42.8 & 8.5 \\
\hline Stand-By & 09/14/1983 & 09/13/1984 & 55.0 & 55.0 \\
\hline
\end{tabular}

VI. Projected Obligations to the Fund ${ }^{10}$ (SDR million; based on existing use of resources and present holdings of SDRs):

Principal

Charges/interest

Total $\underline{\text { Overdue }}$

$7 / 31 / 2006$

223.38

$\underline{298.42}$

521.80

\begin{tabular}{lllll}
\multicolumn{5}{c}{ Forthcoming } \\
2006 & 2007 & 2008 & 2009 & 2010 \\
$\frac{6.09}{6.09}$ & $\frac{12.28}{12.28}$ & $\frac{12.29}{12.29}$ & $\frac{12.27}{12.27}$ & 12.28 \\
\hline .09 & 12.28
\end{tabular}

\footnotetext{
${ }^{10}$ The projection of charges and interest assumes that overdue principal at the report date (if any) will remain outstanding, but that forthcoming obligations will be settled on time.
} 


\section{Exchange Rate Arrangement}

The currency of Liberia is the Liberian dollar. The U.S. dollar is also legal tender. The current exchange rate arrangement is a managed float, with no predetermined path for the exchange rate. The exchange rate of the Liberian dollar is market determined, and all foreign exchange dealers, including banks, are permitted to buy and sell currencies, including the U.S. dollar. Liberia's exchange rate at end-July 2006 was L\$59.5=US\$1.

\section{Article IV Consultation}

The 2006 Article IV consultation discussions were held in Monrovia during February 16March 1, 2006 in Monrovia. The staff report (Country Report No. 06/166, 5/08/06) was discussed by the Executive Board on April 26, 2006.

\section{Technical Assistance}

$\underline{\text { Subject }}$

Mission: currency arrangement

reform

MAE

1995

Mission: currency arrangement and financial system reform

MAE

1998

Advisor: banking commission

MAE short term

Advisor: general operations

MAE long term

1998-2000

Advisor: audit and accounting

MAE long term

$1998-2000$

Advisor: research

MAE long term

1998-2000

Advisor: banking supervision

MAE long term

1999-2001

Mission: assessment of technical assistance needs

MFD

2003

Mission: monetary operations, foreign

MFD

May 2004

exchange, auctions, banking supervision, payments system

Mission: monetary operations, foreign

MFD

Aug. 2004

exchange auctions, banking supervision, payments system

Mission: monetary operations, foreign

MFD

Feb. 2005

exchange auctions, payments system

Mission: bank restructuring

MFD

May 2005

Mission: monetary operations, foreign

MFD

Aug. 2005

exchange auctions, banking supervision,

payments system

Mission: negotiation on chief administrator post MFD

Dec. 2005 
Chief Administrator for the CBL

MFD

Feb. 2006

Mission: bank restructuring, monetary operations,

payment systems, and central bank accounting MFD

June 2006

Mission: budget preparation and expenditure

FAD

1997

Mission: strategy for fiscal reform

FAD

1998

Advisor: budget preparation and classification

FAD short and long term

$1998-2000$

Advisor: budget execution

FAD short and long term

1998-2000

Mission: tax reform

FAD

1999

Mission: preparation of tax code

FAD

1999

Mission: tax administration

FAD

1999

Advisor: tax administration

FAD short term

2000

Mission: assessment of technical assistance needs

FAD

Dec. 2003

Mission : public expenditure management

FAD

May 2004

Mission : public expenditure management

FAD

July 2004

Mission : tax administration

FAD

Sept. 2004

Mission : public expenditure management

FAD

Dec. 2004

Mission : public expenditure management

FAD

Feb. 2005

Mission : forestry tax policy

FAD

Feb. 2005

Mission : public expenditure management

FAD

May 2005

Mission : public expenditure management

FAD

Dec. 2005

Mission : public expenditure management

FAD

Feb. 2006

Mission: public financial management

FAD

March 2006

Mission: tax policy

FAD

May 2006

Mission: revenue administration

FAD

Aug. 2006

Mission: preassessment for multisector statistics

STA

1997

Mission: multisector statistics

STA

1998

Mission: money and banking statistics

STA

1999

Mission: money and banking statistics

STA

1999

Mission: money and banking statistics

STA

2000

Advisor: balance of payments compilation

STA short term

2000

Mission: balance of payments statistics

STA

2000

Mission: assessment for technical

assistance needs

STA

Dec. 2003

Mission: balance of payments statistics

STA

May 2004

Mission: balance of payments statistics

STA

July 2004

Mission: government finance statistics

STA

July 2004

Mission: national accounts

STA

July 2004 
Mission: monetary and financial statistics Mission: government finance statistics Mission: consumer price statistics Mission: government finance statistics
STA

STA

STA

STA
Aug. 2004

Jan. 2006

May 2006

June 2006

X. Resident Representative

A resident representative has been posted in Monrovia since April 3, 2006. 


\section{Appendix III. Liberia-Relations with the World Bank Group}

(As of July 31, 2006)

The World Bank suspended disbursements to Liberia in December 1986 as a result of mounting arrears, and Liberia's loans were placed in nonaccrual status in June 1987. To that date, disbursements had totaled US\$141.3 million from 22 IBRD loans and US\$91.5 million from 17 IDA credits; only US\$ 43.6 million owing on these disbursements has been repaid. By May 30, 2006, Liberia's arrears to the World Bank were US\$456.14 million, reflecting further interest charges. Liberia has an outstanding obligation of US\$2.2 million to the World Bank, since August 24, 2005, to fulfill the Maintenance of Value (MOV) clause in the Bank's Articles of Agreement.

Following the Comprehensive Peace Agreement in August 2003 and the installation of the National Transitional Government of Liberia (NTGL) in October 2003, the Bank co-hosted with the UN and US the International Reconstruction Conference for Liberia in February 2004. In March 2004, the Executive Directors of the Bank discussed the Liberia Country Reengagement Note. In April 2004 a US\$4.0 million grant from the Bank's newly created LICUS Implementation Trust Fund was approved to fund activities in four areas: community empowerment, including a rapid social assessment; public procurement and financial management; forestry sector management; and the coordination and implementation of the Results-Focused Transition Framework (RFTF). A US\$25 million grant from the Bank's IBRD surplus, was endorsed by the Bank's Executive Directors in August 2004 and approved by the Bank's Board of Governors in October 2004. This grant extends funding of the above activities, funds additional activities in the area of infrastructure, and will provide support for the internationally supported Governance and Economic Management Assistance Program (GEMAP) agreed to with the NTGL in September 2005. The first subgrant from this source of funding, the Technical Assistance Component for Infrastructure Rehabilitation (US\$5.0 million), was approved in December 2004, and the second subgrant, Community Empowerment (US\$6.0 million), in February 2005. Other subgrants are being prepared.

In addition to the trust-funded operations mentioned above, the Bank has prepared its first IDA operation for Liberia, the Liberia Emergency Infrastructure Pre-Arrears Clearance Grant of US\$30.0 million which was approved by the Bank's Board on June 20, 2006. This grant will focus on the reconstruction of two primary roads, construction of 6 major bridges and the repair of an additional 65 , restoration of a water treatment plant, and support for the reestablishment of power in Monrovia as well as on strengthening institutional capacity within the Ministry of Public Works to manage the above activities.

Since July 2004 the Bank has had a Senior Country Officer in Monrovia to coordinate the Bank's activities in Liberia. The Bank will open a full Country Office in Monrovia as of July 1, 2006 headed by a Country Manager and supported by several operational and administrative staff. 
The working environment in Liberia is characterized by close coordination and consultation among the government, the Bank, the IMF, the UN group, bilateral donors, local and international NGOs, and civil society. This approach was forged during the transition through the high-level RFTF Implementation and Monitoring Committee, the Liberia Reconstruction and Development Committee, and the Economic Governance Steering Committee of the GEMAP and its Technical Team. In December 2005 the Bank became a member of the International Consultative Group on Liberia.

\begin{tabular}{|c|c|c|c|}
\hline \multicolumn{4}{|c|}{$\begin{array}{c}\text { World Bank Group } \\
\text { Statement of Loans/Credits/Grants for Liberia } \\
\text { Summary in U.S. Dollars at April 30, } 2006\end{array}$} \\
\hline & IBRD & IDA & Total \\
\hline Original Principal & $155,950,000$ & $114,500,000$ & $270,450,000$ \\
\hline Cancellations & $14,693,265$ & $22,765,012$ & $37,458,277$ \\
\hline Disbursed & $141,256,735$ & $91,541,498$ & $232,798,233$ \\
\hline Undisbursed & 0 & 0 & 0 \\
\hline Repaid & $42,874,104$ & 723,744 & $43,597,848$ \\
\hline Due & $97,977,632$ & $107,038,449$ & $205,016,080$ \\
\hline Exchange adjustment & $50,839,079$ & 0 & $50,839,079$ \\
\hline Borrowers' obligation & $148,816,711$ & $107,038,449$ & $255,855,159$ \\
\hline Sold third party & 405,000 & 0 & 405,000 \\
\hline Repaid third party & 405,000 & 0 & 405,000 \\
\hline Due third party & 0 & 0 & 0 \\
\hline
\end{tabular}




\section{Appendix IV. Liberia-Statistical Issues}

1. Substantial weaknesses in Liberia's economic statistics hamper effective surveillance, largely because the civil war caused widespread destruction of databases and the loss of administrative and institutional capacity for statistics. Several STA missions have visited Monrovia in recent years (three so far in 2006) to assist the authorities in rebuilding capacity to compile statistics in the areas of national accounts, price statistics, monetary, fiscal and balance of payments statistics.

2. The government passed legislation in July 2004 to create the Liberia Institute of Statistics and Geo-Information Services (LISGIS) as a semi-autonomous agency. This agency will have the lead in coordinating and reestablishing national economic and social statistics.

3. As one of fifteen countries participating in the Fund's General Data Dissemination System (GDDS) Project for Anglophone African Countries (funded by the U.K. Department for International Development), Liberia has undertaken to use the GDDS as a framework to develop its national statistical system. Metadata and plans for improving the data over the short and medium term were posted on the Fund's Dissemination Standards Bulletin Board (DSBB) on October 24, 2005.

4. The Central Bank of Liberia (CBL) is now regularly reporting monetary and financial and exchange rate statistics for publication in International Financial Statistics (IFS), but their quality and timeliness need to be improved. The CBL also publishes data on money and banking, prices and output, fiscal operations and debt, interest and exchange rates, and foreign trade in its statistical bulletin, Liberia Financial Statistics, on a bimonthly basis with a lag of about six months. It also publishes the quarterly Financial and Economic Bulletin, covering the previous four quarters, with a lag of about six months.

\section{Real sector}

5. Annual estimates of production by sector are prepared by the National Accounts Unit of the Ministry of Planning and Economic Affairs (MPEA). The Fund staff has estimated total GDP by sectoral origin for the period 1997-2005 with the assistance of the MPEA. Estimates for GDP by expenditure are not available. A household survey is required as a base for more reliable data.

\section{Prices}

6. The Price Unit of the MPEA began producing a consumer price index in late 1998, with May 1998 as the start date and reference period. However, the weights are based on an expenditure survey of 100 Monrovia households conducted in 1963-64. Targeted sampling frequencies vary from bimonthly for food items to biannually for rents and personal care and services, and often fall behind schedule. A survey conducted in June 2004 updated two 
subgroups of expenditure - rent and personal care and health services - included in the Monrovia consumer price index. Monthly data have been reported to the Fund in tandem with publication, which generally involves a lag of about two months.

7. The authorities are considering recent STA TA recommendations to replace the Monrovia Consumer Price Index with a Harmonized Consumer Price Index, which is based on an expanded basket of goods and services, and updated weights (using consumption patterns in neighboring countries in the absence of an updated household survey).

\section{Government finance statistics}

8. The authorities regularly provide staff with information on fiscal accounts. The Ministry of Finance provides monthly disaggregated data on government revenue and on current and capital expenditure. There is considerable scope, however, for improving the quality and consistency of the government finance statistics. Data on domestic arrears and on financing items are unreliable. Although Liberia has availed itself of substantial technical assistance under the DFID project for Anglophone Africa, the authorities have not reported data for publication in the Government Financial Statistics Yearbook (GFSY) since 1988, or for the IFS for several years.

\section{Monetary statistics}

9. The CBL has made progress in compiling monetary aggregates according to international standards. However, further steps are needed to strengthen the CBL's accounting system, including properly accounting for foreign reserves and appropriately segregating required reserves by currency denomination and classification of other assets and liabilities. In addition, while the reporting of preliminary statistics by commercial banks has improved, the response by banks to requests for explanations and follow-up to noted inconsistencies continues to be weak. An STA mission in 2006 is expected to address these issues, and also to finalize the standardized report form (SRF) for the CBL, derive the SRF for the other depository corporations based on the accounts of the commercial banks, and work on developing an integrated monetary database.

\section{Balance of payments and external debt}

10. Official balance of payments statistics have not been reported comprehensively since the 1988 Article IV consultation; however, the Fund staff has prepared provisional balance of payments statistics in cooperation with the CBL, the Ministry of Commerce (MoC), MPEA, and the Ministry of Finance (MoF). The CBL is responsible for compiling the balance of payments in coordination with other agencies. Some progress has been made in compiling certain current and financial account components - mainly on trade and related services, government expenditures, remittances, and on nonresident deposits in the financial account - but lack of primary source data and errors in distinguishing between components in services, income and transfers underscore the need for technical assistance in the area of 
capacity building. A stronger effort must be made to resolve and reconcile the significant discrepancies in trade data reported by the various agencies. The CBL has completed a census of foreign direct investment enterprises in preparation for an investment survey following the recommendations made by the STA mission in July 2004.

11. Significant gaps exist in the records of external public debt, particularly those related to bilateral and commercial creditors. A task force comprising staff seconded from the CBL, MoF, MPEA, General Auditing Office (GAO) and the Bureau of the Budget (BOB) is making progress in obtaining loan agreements and financial statements from external creditors to update the external debt database maintained by the MoF. As part of building capacity for balance of payments and external debt statistics compilation, STA trained three Liberian officials in 2005- one in balance of payments and two in debt statistics. STA is planning a follow-up balance of payments technical assistance mission to Liberia in FY 2007. 


\section{Liberia-Table of Common Indicators Required for Surveillance}

As of July 31, 2006

\begin{tabular}{|c|c|c|c|c|c|}
\hline & $\begin{array}{c}\text { Date of } \\
\text { latest } \\
\text { observation } \\
\end{array}$ & $\begin{array}{l}\text { Date } \\
\text { received }\end{array}$ & $\begin{array}{l}\text { Frequency } \\
\text { of Data }^{4}\end{array}$ & $\begin{array}{l}\text { Frequency } \\
\text { of } \\
\text { Reporting }\end{array}$ & $\begin{array}{l}\text { Frequency } \\
\text { of } \\
\text { publication }^{4}\end{array}$ \\
\hline Exchange Rates & July 2006 & Aug. 2006 & $\mathrm{D}$ & M & B \\
\hline $\begin{array}{l}\text { International Reserve Assets and } \\
\text { Reserve Liabilities of the Monetary } \\
\text { Authorities }{ }^{1}\end{array}$ & Jun. 2006 & Jul. 2006 & M & M & B \\
\hline Reserve/Base Money & Jun. 2006 & Jul. 2006 & M & M & $\mathrm{B}$ \\
\hline Broad Money & Jun. 2006 & Jul. 2006 & M & M & B \\
\hline Central Bank Balance Sheet & Jun. 2006 & Jul. 2006 & M & M & $\mathrm{B}$ \\
\hline $\begin{array}{l}\text { Consolidated Balance Sheet of the } \\
\text { Banking System }\end{array}$ & Jun. 2006 & Jul. 2006 & M & M & B \\
\hline Interest Rates & May 2006 & Jul. 2006 & M & M & B \\
\hline Consumer Price Index & Jun. 2006 & Jul 2006 & M & M & B \\
\hline $\begin{array}{l}\text { Revenue, Expenditure, Balance and } \\
\text { Composition of Financing }{ }^{2}- \\
\text { General Government }^{3}\end{array}$ & $\cdots$ & $\cdots$ & $\cdots$ & $\cdots$ & $\cdots$ \\
\hline $\begin{array}{l}\text { Revenue, Expenditure, Balance and } \\
\text { Composition of Financing }{ }^{2}-\text { Central } \\
\text { Government }\end{array}$ & Jun. 2006 & Jul. 2006 & M & M & B \\
\hline $\begin{array}{l}\text { Stocks of Central Government and } \\
\text { Central Government-Guaranteed } \\
\text { Debt }\end{array}$ & Sep. 2005 & Feb. 2006 & Q & $\mathrm{B}$ & $\mathrm{B}$ \\
\hline External Current Account Balance & $\ldots$ & $\cdots$ & $\cdots$ & $\ldots$ & $\ldots$ \\
\hline $\begin{array}{l}\text { Exports and Imports of Goods and } \\
\text { Services }\end{array}$ & Jun. 2005 & Oct. 2005 & M & $\mathrm{Q}$ & $\mathrm{B}$ \\
\hline GDP/GNP & $\ldots$ & $\cdots$ & $\cdots$ & $\cdots$ & $\cdots$ \\
\hline Gross External Debt & Dec. 2005 & Feb. 2006 & Q & B & B \\
\hline
\end{tabular}

${ }^{1}$ Includes reserve assets pledged or otherwise encumbered.

${ }^{2}$ Foreign, domestic bank, and domestic nonbank financing.

${ }^{3}$ The general government consists of the central government (budgetary funds, extrabudgetary funds, and social security funds) and state and local governments.

${ }^{4}$ Daily (D); Weekly (W); Monthly (M); Bi-monthly (B); Quarterly (Q); Annually (A); Irregular (I); Not Available (NA) 
This page intentionally left blank 


\section{IMF Initiates De-Escalation of Remedial Measures Against Liberia and Lifts the Declaration of Noncooperation}

Today, the Executive Board of the International Monetary Fund (IMF) decided to initiate the deescalation of the IMF's remedial measures that have been applied against Liberia. Moreover, to encourage further reform efforts by the Liberian authorities and to provide a positive signal to Liberia's development partners, the Executive Board decided to lift the declaration of noncooperation that had been in place since March 30, 1990. The Board also decided that it could consider lifting the suspension of Liberia's voting and related rights following satisfactory performance regarding economic policies and payments to the IMF during an evaluation period of approximately 12 months from the date of the Board decision.

The Liberian authorities have made considerable progress in implementing its economic program monitored by IMF staff. Macroeconomic developments have been broadly favorable, with GDP growth expected to continue to recover to about 8 percent and inflation projected to be in the single digits in 2006. Financial management has been significantly strengthened under the new government, with strict adherence to a commitment control system designed to ensure that expenditures do not exceed available revenues. The financial position of the Central Bank of Liberia also has improved, and a cash-based balanced budget for fiscal year 2006/07 was approved in late August. Liberia also has made monthly token payments to the IMF.

Today's Board decision is the first step in a process of de-escalation of the remedial measures that have been applied to Liberia. The de-escalation process is designed to encourage members with protracted arrears to the IMF to establish a solid record of policy performance and payments to the IMF, with the ultimate objective of full clearance of arrears and regaining access to IMF financial resources. Substantial financial support from the international community for clearance of arrears and debt relief for Liberia will be needed.

After the Executive Board discussion, John Lipsky, First Deputy Managing Director of the IMF, made the following statement: "Liberia has established an encouraging track record of policy cooperation and payments under the staff-monitored program that began in February 2006. The authorities have committed to further strengthening cooperation with the IMF in terms of both policy and continued payments. This would allow the IMF to give consideration to further

Washington, D.C. 20431 • Telephone 202-623-7100 • Fax 202-623-6772 • www.imf.org 
de-escalate the remedial measures and, with adequate financing assurances, a possible rights accumulation program aimed at clearing Liberia's arrears to the IMF. These actions could pave the way for Liberia to benefit from debt relief under the Highly Indebted Poor Country Initiative and the Multilateral Debt Relief Initiative." 


\section{Statement by Peter Ngumbullu, Executive Director for Liberia and Bhadala T. Mamba, Advisor to Executive Director \\ October 2, 2006}

\section{Key Issues}

- The Liberian authorities have displayed strong commitment to restoring macroeconomic stability and begun the process of reconstruction after decades of civil war, despite the serious capacity constraints it faces.

- The new administration is committed to deepening reforms, building on the SMP, underpinned by aggressive revenue collection, strong expenditure control and structural reforms. They have already promulgated policies and put in place institutions supportive of transparency and accountability, while also dealing with the mammoth challenges of reconstructing the country, leading to a rebound in economic activity. Their objective is to reduce poverty and build a strong, vibrant and competitive economy.

- The authorities have performed exceptionally well and established a commendable track record under the Staff Monitored Program (SMP), meeting all the quantitative and structural benchmarks. They have identified fiscal consolidation as an integral part of their reforms.

- The authorities have improved their cooperation with the Fund and despite difficult financial conditions, have increased their payments to the institution as an attestation to their commitment. They now look forward to the Executive Board approving the de-escalation of the Fund's remedial measures against the country, leading to the final restoration of the country's voting and related rights in the Fund.

- The recovery is still nascent and hinges on the expeditious inflow of financial assistance, in the form of grants from the international community to quicken and deepen the momentum of reforms. They request the donor community to expedite mobilization of financial assistance.

- They further seek the resolution of the crippling external and domestic debt overhang. They request Board's approval to graduate to a Rights Accumulation Program (RAP) with the Fund after the current SMP, paving and accelerating the way for debt relief under HIPC and MDRI, which will also set the stage for increased donor financial inflows, necessary for sustained growth and poverty reduction.

\section{Introduction}

1. The authorities have made commendable progress towards achieving and restoring macroeconomic stability and reconstructing the country within the short space of time 
they have been in office after decades of economic malaise. Liberia, in its process of rebuilding institutions and structures essential for entrenching sustained economic development, growth and poverty reduction, looks to the international community for support of this embryonic endeavor. These reforms are also aimed at improving economic governance and financial management and assist the country move to a comprehensive and final arrears clearance, debt relief resolution and meaningful poverty reduction. The legislature has approved the administration's first budget and the authorities are committed to operate within the approved budget framework, working closely with the international community, who are expected to assist in augmenting their limited resources and providing the much-needed technical support as well.

2. The revitalization of other sectors, like the rubber sector, remain equally important and policies are being put in place to ensure that economic recovery is broad based across all the sectors of the economy. They are grateful for the lifting of the timber ban by the UN and look forward to the lifting of diamond export sanctions as they work on exploiting some of the country's natural resources in a manner that will increase revenues and promote economic growth. The forestry, mining and other resource-based industries have been identified as immediate potential drivers of the economy.

\section{Overview of Financial obligations and Liberia's Heavy Debt Burden}

3. The staff recognizes the commendable achievements made by the authorities under the Staff Monitored Program. The country's unsustainable debt requires urgent and comprehensive resolution if the country is to sustain the growth momentum and achievements already made. The Liberian authorities have made considerable progress in implementing the SMP and have continued monthly payments to the Fund. The authorities will continue to deepen and broaden their reform agenda. However, the major risk to these efforts and achievements is the lack of immediate financial inflows to kick-start and deepen the reforms and the slow progress in securing firm commitments from the donor community to clear arrears and finance the country's HIPC and MDRI debt relief. We believe that the Fund has a crucial role to play in galvanizing such donor backing and support and to fast track the country in securing the urgently needed financial support.

\section{Fiscal Developments}

4. The authorities have significantly transformed the financial management systems of the country and have done-away with previous public management practices. The overall operation of the cash-based budget is overseen by the Cash Management Committee (CMC), which approves government expenditures and ensures that expenditures are in line with the budget. The authorities have also set-up other new structures and are focused on bringing the fiscal situation under control by improving tax revenue collection and controlling expenditure. This has been done by aligning 
the operations of the Ministry of Finance, and bringing the operations of the Bureau of the Budget and other revenue collecting agencies to report directly to the Ministry. These efforts have resulted in a more efficient management and execution of government activities and increased revenue collection.

5. At the heart of the operation of the $\mathrm{CMC}$, is ensuring that no out of budget allotments are made and that all expenditures are matched with the available resources.

Paramount to their work, is entrenching prudent fiscal management cognizant of the limited resource envelope. They are committed to maintain this momentum and hope that donors will provide them with grant resources to augment their cash budget and enable them to deliver more and wider services to the Liberian people.

6. In addition, the authorities have launched a number of initiatives and reforms, including streamlining civil service rules and regulations and reviewing the structures and functions of all the different government ministries. This also includes a payroll audit and civil service census, which involves a comprehensive consultation process before reducing these recommendations into a bill for consideration by the legislature.

7. The authorities have undertaken an extensive training and sensitization exercise regarding the new financial rules and the Procurement Act. As a result, the capacity building efforts and greater familiarity of these rules has significantly improved expenditure processing by senior officials on its requirements and operations. Significant progress has been made to reduce wage and rental arrears, and since the beginning of the financial year, payment of salaries for civil servants was made current, a major departure from the past twenty years of Liberia's fiscal administration.

8. On the revenue side, the recent provisional lifting of the ban on timber exports is expected to improve revenue collection in 2007 and the appropriate legislation is being put in place. The increased activity in the timber sector is also expected to boost employment creation and help in improving economic activity and expanding the tax base. The authorities are in the process of reviewing a number of tax exemptions granted by previous regimes which are undermining revenue collection efforts particularly in the rice and petroleum sector. This effort includes also collecting tax arrears and further strengthening and widening of the tax net. The authorities intend rationalizing the tax rates and expand the tax base reducing the over reliance on tariff revenues. Furthermore, they will continue strengthening the budget by streamlining expenditures with appropriate oversight and explore avenues for increasing revenues.

9. Significant progress has already been made in the verification of domestic debt arrears by an inter-ministerial committee, which will make recommendations to government on the required action. An external expert has been contracted to assist the country deal with the international debt verification and resolution and the Paris Club and other bilateral and commercial creditors are being engaged. 


\section{Monetary Policy Issues}

10. The authorities have implemented most of the financial sector reforms as articulated in the SMP. The exchange rate and inflation has remained relatively stable during the program period. In this vein, the authorities have agreed to gradually infuse the Liberian dollar into the economy while safeguarding the integrity of the exchange rate. They attach significant importance to the various TA missions from the Fund that have been deployed to the Central Bank of Liberia and they value the advice they have proffered. They recognize the need to modernize the country's monetary and financial sector and to keep inflation within manageable levels and strengthen the fiscal policy efforts. They are working hard to create the enabling environment for more investment and higher economic growth. The Central Bank will continue to play its important role in the economy, increase foreign reserve holdings and facilitate efficient operation of the financial sector.

11. The Central Bank has made significant progress in improving its financial health, deal with its budget deficit and address the dollarization issue. Dollarization is seen as stifling economic growth, putting pressures on local banks to recapitalize and is also undermining financial intermediation efforts. The authorities seek assistance of the Fund in dealing with this issue of dollarization and developing a lasting solution to this issue as they work towards returning the country to a higher growth path in a stable macroeconomic environment.

\section{Structural Issues}

12. The authorities are committed to improving the investment environment to be more conducive and reduce the costs of doing business in Liberia. A new investment code is being developed and all bureaucratic processes that stifle investment and prone to corruption are being reviewed. To achieve this, they are continuing to work towards creating an economic atmosphere conducive to job creation, an open trading system with low tariffs, well functioning ports and customs system. The on going-work of reviewing previously issued concessional contracts is expected to also create a new environment for private investment. This is expected to develop further downstream activities in the various sectors of the economy, in the medium-term. At the heart of all these efforts is improving the economic infrastructure, through improving the road network, provision of reliable electricity and all other related services essential for conducting business.

13. The international community is not only expected to help in providing financial resources but assist in the rebuilding of key institutions, provide policy advice and technical assistance while concurrently building local capacities to ultimately take over these responsibilities. The new government is strongly committed to ensuring that international support to the country is well coordinated, efficiently utilized and accounted for to engender principles of good governance, effective development and at the same time reduce poverty. In this respect, the government has set up an 
implementation and coordinating committee, Rimco Support Office (RSO), that will collect information on aid flows and coordinate these flows into the country.

14. The authorities have made significant progress in engendering economic governance. They recognize the importance of a functional and transparent judicial system and a constitution that promotes a healthier balance between the various branches of government. This includes the restoration of peace and healing in the country, which has been strengthened by the recent formation of the Truth and Reconciliation Commission. The authorities are thankful for the support of the international community, particularly the UN in restoring peace and stability in Liberia and the region. They are determined to significantly reduce corruption and have developed a draft anti-corruption paper and are in the process of considering a comprehensive national strategy and the appropriate institutional framework. They have established a Contracts and Concessions Review Committee (CCRC), that is reviewing contracts and concessions signed during the NTGL period.

\section{Poverty Reduction and Reconstruction Efforts}

15. The authorities realize that the peaceful transition is fragile and hinges on dealing with the pervasive poverty in the country, the speedy resolution of internally displaced persons, and ex-combatants who need to return to their places of origin, and who require to be rehabilitated and reintegrated into the Liberian society. Working in collaboration with the UNHCR and other humanitarian agencies, the authorities are making significant progress in relocating internally displaced persons to their places of origin. They are optimistic that the new budget will accommodate the Interim Poverty Reduction Strategy (IPRSP), given the fiscal space coming with the small projected surplus. They also look to the donor community to assist in this area as well. The full PRSP process will be undertaken and will be aligned to the country's macroeconomic framework and budgetary processes.

16. Efforts to improve the social and economic infrastructure are on-going and these are focused on improving water and sanitation facilities and increase the number of people who have access to health facilities in the medium-term.

\section{Conclusions}

17. The challenges facing the country are huge and diverse and it is in this vein that the authorities seek the support and assistance of the international community. The authorities are encouraged by the goodwill shown by their cooperating partners and are working tirelessly to ensure these efforts are well-coordinated and are efficiently executed to fight poverty and reconstruct the country. They greatly appreciate the interest and good will shown by the international community and look forward to further continued engagement as they consolidate the gains and momentum already achieved thus far. They thank the IMF and World Bank for the various missions that have already come to assist the country within the short period that the new 
government has been in power. They greatly appreciate the assistance received from these institutions and the international community as they work tirelessly to implement these reforms, but much more is needed.

18. We all should recognize the urgency of meeting the huge expectation from the Liberian people and respond to the call of the authorities who are working hard to create the enabling environment that will attract FDI into the country and create jobs and improve delivery of social services while working within the tight budgetary commitments and constraints. They believe that the continued peaceful transition remains crucial for improving the investment climate and the future economic strategies. They count on the immediate assistance of the international community to deal with the debt overhang, which they see as the biggest threat to engendering a sustainable growth path for the country. They urge donors to quickly raise the resources needed for Liberia's arrears clearance and call on the Fund to catalyze this process. 